\title{
Supplier selection for vendor-managed inventory in healthcare using fuzzy multi-criteria decision-making approach
}

\section{Detcharat Sumrit $^{\mathrm{a}^{*}}$}

${ }^{a}$ The Cluster of Logistics and Rail Engineering, Faculty of Engineering, Mahidol University, Thailand

\begin{tabular}{l}
\hline C H R O N I C L E \\
\hline Article history: \\
Received August 25, 2019 \\
Received in revised format: \\
September 25, 2019 \\
Accepted October 7, 2019 \\
Available online \\
October 7, 2019 \\
\hline Keywords: \\
Vendor managed inventory \\
Multi-criteria decision making \\
Fuzzy Delphi \\
Fuzzy SWARA \\
Fuzzy CORPRAS
\end{tabular}

\section{Introduction}

Presently, organizations in the healthcare sector are facing many challenges to accomplish the balance between quality improvement and cost effectiveness. The growth of healthcare industry has been accelerated in the past several years, resulting inventory management of hospitals to be become a crucial issue in healthcare service providers (Kwon et al., 2016). In fact, the healthcare organizations have to make a trade-off between stock outs and on-shelf availability against the pharmaceutical wastage due to an expiry for their medication products (Weraikat et al., 2019). Moreover, any shortage case in medication supplies can lead serious consequences on the illness or the fatality of patients. Singh (2013) observed that the effective inventory management is an important strategy for healthcare organizations to enhance their competitiveness. It is widely accepted that Vendor-Managed Inventory (VMI) is regarded as a stock management in supply chain model to balance overall operations of partners by delivering both effectiveness and efficiency in supply chain (Yu et al., 2015). VMI is also an initiative and collaborative tool that allows suppliers authorized to manage inventory of customers (Kros et al., 2019). A great deal of evidences from previous studies have presented that VMI provides many benefits to various industries. Savasaneril and Erkip (2010) indicated that VMI can generally

\footnotetext{
* Corresponding author.

E-mail address: dettoy999@gmail.com (D. Sumrit)

(C) 2020 by the authors; licensee Growing Science, Canada. doi: $10.5267 /$ j.dsl.2019.10.002
} 
offers benefits to both suppliers and customers via their agreement frameworks in order to ensure product availability for customers and to provide flexibility to suppliers. In the same way, the study of Yao et al. (2007) also defined that there are higher potential economic benefits after adopting VMI such as inventory cost reduction for the suppliers, and service level improvement for customers, i. e., higher repeated rate.

Several empirical researches have broadly conducted VMI usages, applications, and enablers, which are in various business in manufacturing sectors like automotive, electronics, telecommunication, retail industries and even hospital (Dong \& Xu, 2002). For example, the optimal pricing and lot sizing vendor managed inventory (Ziaee \& Bouquard, 2010), a comparison of performance results of VMI practices and define enablers of successful VMI usages (Classen, et al., 2008). Some literatures have discussed VMI in various useful aspects of manufacturing sectors; for example, production- distribution planning/supply chain management (Niknamfar, 2015), home appliances industry ( Tony \& Zamalo, 2005), inventory and pricing policies in non-cooperative supply chain (Naeij \& Shavandi, 2010). Regarding to VMI advantages, it is increasingly used in many industries for day-to-day operations of several organizations. The successful VMI implementation can contribute numerous benefits to improve supply chain performance of hospitals, i.e., the improvement of efficiency, responsiveness, and replenishment process; the reduction of unnecessary overstocks or stocks out situations; including decreasing uncertainty for production and operational planning and so on (Volland et al., 2017). As pinpointed by Kim (2005), VMI implementation program of hospitals can lead $30 \%$ of stock reduction in medical and pharmaceutical products. Moreover, there might be some barriers of VMI practices in healthcare sector such as lacking of knowledge and skills in supply chain management, i.e., technology involvement, standardize code, physician preference, information sharing limitation and poor supplier selection (Guimarães et al., 2013). Krichanchai and MacCarthy (2017) stressed that suppliers play an important role in achieving VMI project initiative. The supplier selection should be careful since it is one of the crucial organizational decisions for VMI implementation and greatly depend on suppliers (Classen et al., 2008). Bhakoo et al. (2012) found that a poor supplier selection decision-making consequently brought the negative impact of VMI performance.

There is an increasing trend to adopt outsourcing inventory decision to suppliers in healthcare sector because many hospitals pursue to improve inventory costs and service levels to deliver their services in time manner (Kwon et al., 2016). Hence, the appropriated supplier selection in VMI program is significantly crucial to reach the success of healthcare organization which relies on the supplier's capabilities and performances. Even though there have been numerous bodies of knowledge from literature related to supplier selection, there are still the limited studies on supplier selection toward initiative VMI. From the extensive literature, this paper is deemed as the first pioneer in VMI supplier selection in context of healthcare sector. Thus, this research attempts to fill a gap within the body of knowledge by proposing a comprehensive framework for selecting VMI supplier. To obtain aforementioned above, this study has five following objectives especially in healthcare context: (i) to propose a comprehensive fuzzy decision making framework for VMI supplier selection in healthcare context, (ii) to identify evaluation criteria for VMI supplier selection, (iii) to determine the relative importance weights of the VMI supplier selection criteria, (iv) to select the potential supplier for VMI implementation by using a famous public hospital in Thailand as a case study, and (v) to address managerial and practical implications.

This paper provides three genuine contributions as follows. Firstly, the study conducted extensive literature to develop a set of evaluation criteria, which specifically uses for VMI supplier selection. Secondly, this study proposed comprehensive Fuzzy MCDM framework for VMI supplier selection by taking vagueness and uncertain human decision making into consideration. Finally, the proposed framework was applied to select the best VMI supplier by using one of the famous public hospitals in Thailand as a case study.

The rest of the paper is organized as follows: it starts with an overview of VMI literature and the fields of VMI in healthcare sector and methodology theoretical theories supporting for this research. Then it 
discusses the proposed research framework and problem descriptions before transitioning to results. Last section includes conclusions, implications, and directions for future research.

\section{Literature Review}

\subsection{VMI in Healthcare Industry}

Traditionally, owners or managers in healthcare industry has paid less attention to supply chain management, especially to inventory management. Actually, this concern has significantly been recognized due to pressures of inventory cost and huge physical \& information flow of medical and pharmaceutical products (Guimarães et al., 2013). The VMI implementation in hospital is considered as one of the most effective integrated tools for both suppliers and hospitals. Its purposes are to (i) reduce inventory levels \& transportation costs, (ii) improve levels of resources supply, speed, and product availability, (iii) increase customer service levels and (iv) reach a higher accuracy of forecasting and demand planning (Kim 2005). Healthcare products normally divide to medicine and pharmaceutical supplies. It is highly potential to adopt VMI for the pharmaceutical products because the pharmaceutical suppliers have knowledge on material management, acquaintance with information technologies (IT) and supply chain management with the best practices (Kim, 2005). In addition, pharmaceutical sector has been strategically implementing IT solutions from entire logistics processes as cross-docking to VMI, streamlining the replenishment process (Shih et al., 2009).

VMI in healthcare industry can create the effective supply for both healthcare organizations and suppliers to reduce the inventory cost. Simultaneously, it is very useful for hospital warehouse management to improve inventory levels \& product availability, develop accuracy \& speed of resources or supply, and reach the most effective distribution of resources (Hui, 2010). Healthcare industry operations are mainly to manage costs for purchasing inventory in the appropriated amounts without overstocking. By VMI implementation, suppliers can assist healthcare organization to identify the replenishment of stocks based on frequency, volume and time. Also they can reach ordering flexibility, reduce lead time variability \& transportation costs, optimize physical distribution, increase warehouse efficiency, access to real time information, and enhance competitive advantage relations (Sui, 2010). Despite several benefits, there might be potential risks related to VMI implementation; for example, shortage of trust and reliability among supplier partners, high investment cost, especially in IT infrastructure in order to accommodate information sharing and time consuming. Other problems on VMI implementation also cover long purchase ordering process, less electronic process, lack of controlling power and forecast sales of suppliers (Ngampunvetchakul, 2014). Also there might be some barriers of VMI practices in healthcare sector; such as lacking of knowledge and skills in supply chain management, i.e., technology involvement, standardize code, physician preference, information sharing limitation and poor supplier selection (Guimarães et al., 2013). Nevertheless, only few prior researches have studied in healthcare sector (Matopoulos \& Michailidou, 2013).

There are several previous studies analyzing total costs of supply chain from VMI adaption; notwithstanding there are some problems on making a decision on inventory levels or supply chain cost without sharing information at point of sale. Then such VMI models could not be well performed since vendor could not access the real demands of products and unable to forecast inventory level. Few research studied VMI implementation be successful in hospital, e.g., Dong and Xu (2002) represented VMI benefits to be useful to reduce stock holding; Classen, et al. (2008) suggested supplier relationship with good IT infrastructure resulted from VMI usage; Hui (2010) suggested supply chain management in hospital based on VMI; and Bhakoo et al. (2012) found that various benefits were perceived from collaborative agreements among supply chain of hospital partners. Moreover, healthcare sector, as a part of service industry, has been extensively studied in several aspects; for example, an influence of the related parties through inventory systems in healthcare (De Vries, 2011), a making decision on an appropriated product selection for professional healthcare staffs (Chen et al., 2013), an explore of the impact of VMI practices on warehouse and inventory management of hospital (Ngampunvetchakul, 
2014); cost-benefit sharing in healthcare supply chain collaboration (Niemsakul et al., 2018); a multicriteria decision making model for readiness assessment of vendor managed inventory in healthcare (Sumrit, 2019); and a generic framework for hospital supply chain (Ziat et al., 2019).

\subsection{VMI Supplier selection criteria}

One of the essential procedures in Multi-Criteria Decision Making (MCDM) approach is the determination of the proper criteria. Since, from many previous studies, the criteria of VMI supplier selection in healthcare sector are rarely addressed. Hence, this study focuses on the extracted criteria from VMI both in healthcare and related neighbor service industries. The lists of applicable of such criteria is carefully developed as displayed in Table 1.

\section{Table 1}

Lists of criteria used for the VMI supplier selection

\begin{tabular}{|c|c|}
\hline Criteria & Description and related literature review \\
\hline $\begin{array}{l}\text { Past delivery } \\
\text { performance }\end{array}$ & $\begin{array}{l}\text { Refers to the ability of the pharmaceutical supplier consistently supplies the acceptable healthcare products to hospital } \\
\text { warehouse at the predefined delivery schedule. Such performances include the abilities to manage lead time, on time, } \\
\text { location and fill rate. The well performed supplier in delivery performance should have a potential to engage VMI in hospital } \\
\text { (Krichanchai \& MacCarthy (2017). }\end{array}$ \\
\hline Institutional trust & $\begin{array}{l}\text { Defines as pharmaceutical suppliers honestly show their trust, and real motivations, goals, and agendas for VMI process. } \\
\text { Abdallah et al., (2017) affirmed that the suppliers need to develop trust and a relationship with their healthcare providers to } \\
\text { collaborate and share information pertained to demand and inventory levels. }\end{array}$ \\
\hline Investment cost & $\begin{array}{l}\text { Refered to VMI total investment cost of the initiative project implementation of both hospital and pharmaceutical supplier. } \\
\text { VMI implementation may create cost burden because it is certainly required investment and restructuring costs, which would } \\
\text { consume both parties' working capitals (Dong et al., 2007). }\end{array}$ \\
\hline $\begin{array}{l}\text { Information sharing } \\
\text { and exchanging }\end{array}$ & $\begin{array}{l}\text { Refers to process which a hospital and a pharmaceutical supplier timely and jointly share and exchange a range of relevant } \\
\text { and accurate information. Raweewan and Ferrell (2018) mentioned that information sharing between healthcare provider } \\
\text { and medical suppliers can lead to reduce uncertainty in inventory management collaboration. Ramanathan }(2012) \text { also } \\
\text { confirmed that information sharing would support the supply chain partners to collaborate in inventory polling and joint } \\
\text { replenishments. }\end{array}$ \\
\hline $\begin{array}{l}\text { Continuous } \\
\text { improvement }\end{array}$ & $\begin{array}{l}\text { Defines as the ability of a pharmaceutical vendor to consistently conduct of continuous improvement activities in VMI } \\
\text { process. Kwon et al., (2016) presented that a lack of suppliers' capability and skills in performing continuous improvement } \\
\text { caused a healthcare provider unwilling to adopt VMI. }\end{array}$ \\
\hline $\begin{array}{l}\text { Supply chain process } \\
\text { integration }\end{array}$ & $\begin{array}{l}\text { Refers to the hospital and the pharmaceutical supplier integrate the relevant supply chain processes incorporation with VMI } \\
\text { management. Shou et al., (2018) stressed that supply chain integration can enhance information-sharing mechanisms } \\
\text { between both parties. Also, Flynn et al., (2016) defined the establishment of supply chain integration process is essential for } \\
\text { VMI project initiative. }\end{array}$ \\
\hline $\begin{array}{l}\text { Information } \\
\text { technologies readiness }\end{array}$ & $\begin{array}{l}\text { Refers to enabling information technology used in managing supply chain operation by the pharmaceutical supplier. The } \\
\text { VMI implementation needs to handle the complicated flow both information and physical stocks for dealing with demand } \\
\text { uncertainty (Kros et al., 2019). Supplier still requires sophisticated information technology system to manage such complex } \\
\text { operation (Moons et al., 2019). }\end{array}$ \\
\hline Supplier flexibility & $\begin{array}{l}\text { Refers to the ability of the pharmaceutical supplier to respond the changing of hospital's demand and requirements. Jayaram } \\
\text { et al., (2011) noted that supplier's flexibility could influence VMI adoption for many organizations. Supplier flexibility } \\
\text { facilitates the positive impact of the relational buyer-supplier strength (Yang et al., 2019). }\end{array}$ \\
\hline $\begin{array}{l}\text { Project } \\
\text { implementation time }\end{array}$ & $\begin{array}{l}\text { Refers to length of time to complete VMI initiative project implementation between a pharmaceutical vendor and the } \\
\text { hospital, Dong et al., (2007) examined that healthcare provider tends to resist VMI adoption if project spends much time } \\
\text { length. }\end{array}$ \\
\hline Devoted resources & $\begin{array}{l}\text { Refers to a commitment resources from a pharmaceutical vendor to setup and implement VMI system. The VMI system } \\
\text { implementation might require the use of robust information technologies such as electronic data interchange (EDI) and data } \\
\text { tracking devices, which are considerably expensive to establish and maintain (Vigtil, 2007). Hence, lack of supplier' devoted } \\
\text { resources is one of the obstacles for VMI project initiative (Dong et al., 2007). }\end{array}$ \\
\hline Spatial complexity & $\begin{array}{l}\text { Refers to the geographic distance between the pharmaceutical supplier warehouse and hospital in order to execute } \\
\text { replenishment in VMI process. The literature highlighted that the considerable geographical distance between the healthcare } \\
\text { provider and the pharmaceutical vendor is negatively affected to VMI feasibility because risks in supply chain disruption } \\
\text { would possibly lead to severe consequences for healthcare service (Danese, 2007). }\end{array}$ \\
\hline $\begin{array}{l}\text { Prior knowledge and } \\
\text { experience }\end{array}$ & $\begin{array}{l}\text { Defines as the level of technological knowledge and experience of pharmaceutical supplier in handling similar VMI project. } \\
\text { Vigtil (2007) observed that the supplier' prior experience in VMI project can lead to greater advantages such as cost saving, } \\
\text { quality improvement, mitigate risk in inventory collaboration processes. }\end{array}$ \\
\hline Risk/ Reward Sharing & $\begin{array}{l}\text { Define as the agreement between the pharmaceutical supplier and hospital in sharing of costs, risks, and benefits for VMI } \\
\text { processes. Uncertainties in demand and pricing of healthcare products result in a situation where the pharmaceutical supplier } \\
\text { and the hospital supplier encountering the risk of shortages, delays and financial losses (Danese, 2007). }\end{array}$ \\
\hline $\begin{array}{l}\text { Reputation and } \\
\text { position in industry }\end{array}$ & $\begin{array}{l}\text { Define as the ranking and reputation of the pharmaceutical supplier compared with its competitors in the same industry in } \\
\text { term of brands, products and firms image. According to Watt et al., (2010), supplier reputation is recognized as an important } \\
\text { criterion in overall evaluation of company. }\end{array}$ \\
\hline
\end{tabular}




\subsection{MCDM Methodology}

\subsubsection{Fuzzy set theory}

In 1965, Fuzzy set theory was introduced by Zadeh (1965) to deal with problems involving uncertainty, vagueness, and the utilization of linguistic terms to describe the decision maker's choices. Linguistic terms are utilized to represent variables, which are associated with fuzzy sets and membership function. Linguistic terms are expressed by natural sentences and converted into triangular fuzzy numbers (TFNs). TFNs were practically applied to handle the vagueness of the linguistic assessments and to contribute the easy usage and computation (Kannan et al., 2014). Many research have applied fuzzy theory in various context; for example, Raad N.G. et al., (2019) used fuzzy MCDM to select a portfolio of projects considering both optimization and balance of sub-portfolios. Abbady et al. (2019) applied fuzzy sets approach for big data governance, dynamic capability and decision-making effectivenes. Chatterjee and Bose (2013) employed fuzzy MCDM for selection of vendors for wind farm. In this study, linguistic terms from Table 2 is used to calculate the relative importance weight of criteria and Table 3 is displayed the rating scale for alternatives. TFNs can be formed by using a triplet $(l, m, u)$ where the membership function of the fuzzy number $F(x)$ is defined in Fig. 1 and expressed as in Eq. (1) (Kannan et al., 2014):

$$
F(x)= \begin{cases}\frac{x-l}{m-l} & l \leq x \leq m \\ \frac{u-x}{u-m} & m \leq x \leq u \\ & \text { otherwise }\end{cases}
$$

Some essential algebraic operation definitions and fundamental of the important properties of fuzzy sets are illustrated as Eqs. (2)-(5). Let $A_{1}=\left(l_{1}, m_{1}, u_{1}\right)$ and $A_{2}=\left(l_{2}, m_{2}, u_{2}\right)$ are two TFNs. Then the functional rules of two triangular fuzzy numbers are shown as below:

Fuzzy addition:

$\mathrm{A} 1 \oplus \mathrm{A} 2=\left(l_{1}+l_{2}, m_{1}+m_{2}, u_{1}+u_{2}\right)$

Fuzzy subtraction:

$\mathrm{A} 1 \ominus \mathrm{A} 2=\left(l_{1}-l_{2}, m_{1}-m_{2}, u_{1}-l_{2}\right)$

Fuzzy multiplication:

$\mathrm{A} 1 \otimes \mathrm{A} 2=\left(l_{1} l_{2}, m_{1} m_{2}, u_{1} u_{2}\right)$

Fuzzy division:

$\mathrm{A} 1 \oslash \mathrm{A} 2=\left(l_{1} / u_{2}, m_{1} / m_{2}, u_{1} / l_{2}\right)$

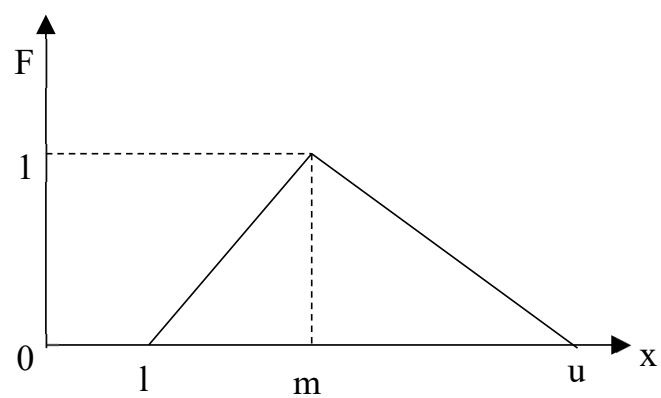

Fig. 1. Membership function of triangular fuzzy number 


\subsubsection{Linguistic variable}

A linguistic variable is a variable that is expressed in linguistic terms such as artificial words or natural sentences which are then displayed by triangular fuzzy numbers (Kannan et al., 2014). This study adopted linguistic scale from Table 2 to derive the relative importance weight of criteria. And Table 3 shows the linguistic scale to evaluate the ratings of alternatives.

Table 2

The fuzzy scale for the relative weight of criteria (Chang, 1996)

\begin{tabular}{lc}
\hline Linguistic assessment scale & Triangular Fuzzy Number \\
\hline Equally important (EI) & $(1,1,1)$ \\
Moderately less important (MI) & $(2 / 3,1,3 / 2)$ \\
Less important (LI) & $(2 / 5,1 / 2,2 / 3)$ \\
Very less important (VI) & $(2 / 7,1 / 3,2 / 5)$ \\
Much less important (MuI) & $(2 / 9,1 / 4,2 / 7)$ \\
\hline
\end{tabular}

Table 3

Linguistic scale to evaluate the ratings of alternatives (Chang, 1996)

\begin{tabular}{cc}
\hline Linguistic assessment scale & Triangular Fuzzy Number \\
\hline $\operatorname{Very} \operatorname{low}(V L)$ & $(0,0,0.25)$ \\
$\operatorname{Low}(L)$ & $(0,0.25,0.5)$ \\
$\operatorname{Medium}(M)$ & $(0.25,0.5,0.75)$ \\
$\operatorname{High}(H)$ & $(0.5,0.75,1)$ \\
$\operatorname{Very} \operatorname{High}(V H)$ & $(0.75,1,1)$ \\
\hline
\end{tabular}

\subsubsection{Fuzzy Delphi}

The Fuzzy Delphi method is an integration of fuzzy set theory and traditional Delphi method (Lee et al., 2010). Fuzzy Delphi has major advantages such as reducing the number of rounds in required survey; appropriately dealing with vagueness, ambiguity and uncertainty in experts' judgment decision process; and gaining economic and effectiveness in term of time and cost in surveys process. This study applied Fuzzy Delphi method by using the paired TFNs in a scale from 1 to 10 (Wei \& Chang, 2008). The stage of Fuzzy Delphi method is presented as follows (Wang, 2015):

Step 1: Organize the Fuzzy Delphi-based questionnaire to gather data from a group of experts. By using score value ranging from 1 to 10 , each expert provides his or her score values for both most pessimistic (minimum) and most optimistic (maximum) for each criteria $\left(i^{\text {th }}\right)$.

Step 2: Examine data obtained from step1 and remove outlier data from each criteria $\left(i^{\text {th }}\right)$, which are outside two standard deviations for both pessimistic and optimistic groups. From the remaining of data, the minimum $\left(P_{L}^{i}\right)$, geometric mean $\left(P_{M}^{i}\right)$, and maximum $\left(P_{U}^{i}\right)$ of pessimistic group for each criteria $\left(i^{t h}\right)$ are determined. By the same way, the minimum $\left(O_{L}^{i}\right)$, geometric mean $\left(O_{M}^{i}\right)$, and maximum $\left(O_{U}^{i}\right)$ of optimistic group for each criteria $\left(i^{\text {th }}\right)$ are obtained.

Step 3: Establish TFNs of pessimistic value $P^{i}=\left(P_{L}^{i}, P_{M}^{i}, P_{U}^{i}\right)$ and optimistic values $O^{i}=\left(O_{L}^{i}, O_{M}^{i}, O_{U}^{i}\right)$ for each criteria $\left(i^{t h}\right)$ as displayed in Fig. 2. According to Fig. 2, the overlapping area of two TFNs $\left(P^{i}\right.$ and $O^{i}$ ) is defined as grey zone (Lee et al., 2010). The grey zone is used to verify the consistent of experts' judgment for each criteria by comparison with the consensus significance value $\left(G^{i}\right)$. The greater $G^{i}$ is, the higher level of experts' consensus. Thus, it is implied that criteria $i^{\text {th }}$ is an important criterion.

Step 4: Check the consistency of experts' judgments and compute the consensus significance value $\left(G^{i}\right)$ for each criteria $\left(i^{\text {th }}\right)$ as three following conditions: 
Condition 1: The paired TFNs between pessimistic value $\left(P^{i}\right)$ and optimistic values $\left(O^{i}\right)$ do not overlap $\left(P_{U}^{i} \leq O_{L}^{i}\right)$, indicates that there is a consensus in criteria $i^{\text {th }}$. Hence the consensus significance value is computed by Eq. (6).

$$
G^{i}=\frac{P_{M}^{i}+O_{M}^{i}}{2}
$$

Condition 2: The paired TFNs between pessimistic value $\left(P^{i}\right)$ and optimistic values $\left(O^{i}\right)$ do overlap $\left(P_{U}^{i}>O_{L}^{i}\right)$ and grey zone interval value $\left(Z^{i}=P_{U}^{i}-O_{L}^{i}\right)$ is less than the interval value $P^{i}$ and $O^{i}\left(M^{i}=\right.$ $\left.O_{U}^{i}-P_{M}^{i}\right)$.Then the consensus significance value of each criteria is computed by Eq. (7).

$$
G_{i}=\frac{\left[\left(P_{U}^{i} \times o_{M}^{i}\right)-\left(o_{L}^{i} \times P_{M}^{i}\right)\right]}{\left[\left(P_{U}^{i}-P_{M}^{i}\right)+\left(o_{M}^{i}-O_{L}^{i}\right)\right]}
$$

Condition 3: The paired TFNs between pessimistic value $\left(P^{i}\right)$ and optimistic values $\left(O^{i}\right)$ do overlap $\left(P_{U}^{i}>O_{L}^{i}\right)$ and grey zone interval value $\left(Z^{i}=P_{U}^{i}-O_{L}^{i}\right)$ is greater than the interval $P^{i}$ and $O^{i}\left(M^{i}=O_{U}^{i}\right.$ $\left.-P_{M}^{i}\right)$. It is indicated that there are discrepancies among expert judgments. Then, step 1-4 are repeated until each criteria is reached to consensus and $G^{i}$ is recalculated.

Step 5: Set up the threshold value $(\tau)$ for selecting appropriate criteria. By making comparison between consensus significance value $\left(G^{i}\right)$ and threshold value $(\tau)$, the evaluation criteria that consensus significance value is less than threshold value $\left(G^{i}<\tau\right)$ will be removed from consideration, otherwise it is accepted. Based on pareto $80 / 20$ rule that " $20 \%$ of the factors account for an $80 \%$ degree of importance of all factors", the threshold value $(\tau)$ ) is arbitrary set as $\tau=8$ (Somsuk \& Laosirihongthong, 2017).

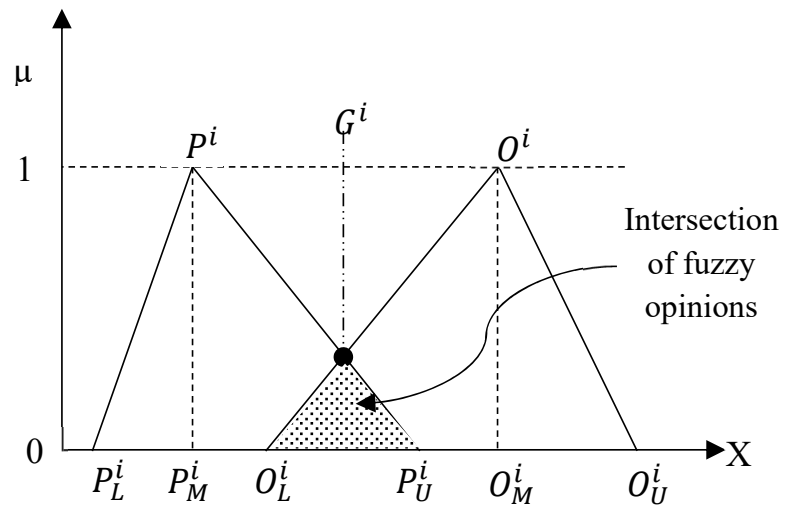

Fig. 2. TFNs formed in the FDM

\subsubsection{Fuzzy SWARA}

The Step-wise Weight Assessment Ratio Analysis (SWARA) approach was introduced by Keršullene et al., (2010). According to Persin (2018), SWARA is one of new decision approaches, which is applied to derive the relative importance weights of criteria or perspective.

The distinctive advantage of this approach is not necessity for making several rounds in criteria weights of pairwise comparison; like analytic hierarchy process (AHP) or analytic network process (ANP) (Mardani et al., 2017). Hence, it is simplicity in coordinating and gathering data from group of experts. SWARA has been widely adopted to solve multi-criteria decision making (MCDM) problems in various contexts, e.g., Eghbali-Zarch et al. (2018) applied SWARA in pharmacological therapy selection of type II of diabetes; and Yazdani et al. (2019) used SWARA for evaluating supply chain risk management under a circular economy context. The SWARA procedure is illustrated in following steps (Keršullene et al., 2010).

Step 1: Arrange the evaluating criteria in descending order based on the expected significant opinions of decision makers (DMs). 
Step 2: Determine the relative importance ratio $\left(S_{j}\right)$ for criteria $j$ with respect to the previous criterion $(j-1)$ by using linguistic term, as displayed in Table 2, starting from the second criteria to the last one. After collecting the values of $S_{j}$ from all DMs, the aggregation of relative importance ratio $\left(\widetilde{S_{J}}\right)$ is obtained by using arithmetic mean; where $\widetilde{S}_{J}=\left(\tilde{S}_{j}^{l}, \tilde{S}_{j}^{m}, \tilde{S}_{j}^{u}\right)$.

Step 3: Calculate the coefficient of comparative importance $\widetilde{k_{J}}$ for each evaluation criteria as Eq. (8).

$$
\tilde{k}_{j}=\left\{\begin{array}{cc}
1 & j=1 \\
\tilde{S}_{J}+1 & j>1
\end{array} \quad \text { where } \widetilde{k}_{J}=\left(\tilde{k}_{j}^{l}, \tilde{k}_{j}^{m}, \tilde{k}_{j}^{u}\right)\right.
$$

Step 4: Compute the intermediated weight $\left(\widetilde{q_{J}}\right)$ for each evaluation criteria as Eq. (9).

$$
\tilde{q}_{j}=\left\{\begin{array}{cc}
1 & j=1 \\
\frac{\tilde{q}_{j-1}}{\tilde{k}_{j}} & j>1
\end{array} \quad \text { where } \widetilde{q}_{J}=\left(\tilde{q}_{j}^{l}, \tilde{q}_{j}^{m}, \tilde{q}_{j}^{u}\right) .\right.
$$

Step 5: Determine the relative importance weights $\left(\widetilde{w}_{j}\right)$ of the evaluation criteria as Eq. (10).

$$
\tilde{w}_{j}=\frac{\tilde{q}_{j}}{\sum_{k=1}^{n} \tilde{q}_{k}}
$$

where $\widetilde{w}_{j}$ denotes the relative weight of criterion $j$ and $n$ represents the number of such criteria; $\widetilde{w}_{j}=$ $\left(\widetilde{w}_{j}^{l}, \widetilde{w}_{j}^{m}, \widetilde{w}_{j}^{u}\right)$.

Step 6: Convert the fuzzy relative importance weights $w_{j}$ to non-fuzzy (crisp value) based on Center of Area (COA) method by Eq. (11).

$$
w_{j}^{n o n}=\frac{\left(w_{j}^{u}-w_{j}^{l}\right)+\left(w_{j}^{m}-w_{j}^{l}\right)+\left(w_{j}^{l}\right)}{3}
$$

\subsubsection{Fuzzy COPRAS}

Complex Proportional Assessment of Alternatives (COPRAS) was introduced by Zavadskas, et al. (1994) to be an analytic and quantitative technique of Multiple Criteria Decision Making (MCDM) for prioritizing the alternatives. This approach applies a stepwise ranking and evaluation procedure of the alternatives by comparing their significance and utility degrees. COPRAS has been successfully adopted to solve the decision making problems in many fields such as sustainable third-party reverse logistics provider evaluation and selection (Zarbakhshnia et al., 2018); hydrogen mobility roll- up site selection (Schitea et al., 2019); severity assessment of chronic obstructive pulmonary disease (Zheng et al., 2018), etc. The ranking procedure of Fuzzy COPRAS are stepped as follows:

Step 1: Determine the fuzzy decision matrix for alternatives rating by using triangular fuzzy numbers as Eq. (12).

$$
\tilde{X}_{k}=\left[\begin{array}{ccc}
\left(x_{11 k}^{l}, x_{11 k}^{m}, x_{11 k}^{u}\right) & \left(x_{12 k}^{l}, x_{12 k}^{m}, x_{12 k}^{u}\right) \ldots & \left(x_{1 n k}^{l}, x_{1 n k}^{m}, x_{1 n k}^{u}\right) \\
\ldots & \ldots & \ldots \\
\ldots & \ldots & \ldots \\
\left(x_{m 1 k}^{l}, x_{m 1 k}^{m}, x_{m 1 k}^{u}\right) & \left(x_{m 2 k}^{l}, x_{m 2 k}^{m}, x_{m 2 k}^{u}\right) \ldots & \left(x_{m n k}^{l}, x_{m n k}^{m}, x_{m n k}^{u}\right)
\end{array}\right]
$$

where $m$ represents the number of alternatives, $n$ represents the number of criteria and $x_{i j}$ is the performance rating of alternative $i$ with respect to criteria $j$ evaluated by decision maker $\mathrm{k},(\mathrm{k}=$ $1,2, . ., \mathrm{K})$. The fuzzy numbers $\left(\mathrm{x}_{\mathrm{ijk}}, \mathrm{x}_{\mathrm{ijk}}, \mathrm{x}_{\mathrm{ijk}}\right)$ stand for the rating score assign to each alternative based on Table 3. 
Step 2: Obtain the fuzzy aggregated decision matrix, $\tilde{X}$; by Eqs. (13)-(14)

$$
\tilde{X}=\left[\begin{array}{ccc}
\left(x_{11}^{l}, x_{11}^{m}, x_{11}^{u}\right) & \left(x_{12}^{l}, x_{12}^{m}, x_{12}^{u}\right) \ldots & \left(x_{1 n}^{l}, x_{1 n}^{m}, x_{1 n}^{u}\right) \\
\ldots & \ldots & \ldots \\
\ldots & \ldots & \ldots \\
\left(x_{m 1}^{l}, x_{m 1}^{m}, x_{m 1}^{u}\right) & \left(x_{m 2}^{l}, x_{m 2}^{m}, x_{m 2}^{u}\right) \ldots & \left(x_{m n}^{l}, x_{m n}^{m}, x_{m n}^{u}\right)
\end{array}\right]
$$

where;

$$
x_{i j}^{l}=\frac{\sum_{k=1}^{K} x_{i j k}^{l}}{K}, x_{i j}^{m}=\frac{\sum_{k=1}^{K} x_{i j k}^{m}}{K}, x_{i j}^{u}=\frac{\sum_{k=1}^{K} x_{i j k}^{u}}{K}
$$

Step 3: Perform the normalized fuzzy aggregated decision matrix and to enhance the comparable capability (Kaklauskas et al., 2006) by using Eqs. (15)-(16). The normalization of initial fuzzy decision matrix is firstly derived by fuzzy CORPAS, which the computation is improved to be more efficient and accuracy.

$$
\begin{array}{ll}
\text { Since } & \tilde{Y}_{i j} \quad=\left(Y_{i j}^{l}, Y_{i j}^{m}, Y_{i j}^{u}\right) \text { for } \forall_{i j}: \\
Y_{i j}^{l} \quad=\frac{X_{i j}^{l}}{\sqrt{\sum_{m}^{i=1}\left[\left(X_{i j}^{l}\right)^{2}+\left(X_{i j}^{m}\right)^{2}+\left(X_{i j}^{u}\right)^{2}\right]}} \\
Y_{i j}^{m} \quad=\frac{X_{i j}^{m}}{\sqrt{\sum_{m}^{i=1}\left[\left(X_{i j}^{l}\right)^{2}+\left(X_{i j}^{m}\right)^{2}+\left(X_{i j}^{u}\right)^{2}\right]}} \\
Y_{i j}^{u} \quad=\frac{X_{i j}^{u}}{\sqrt{\sum_{m}^{i=1}\left[\left(X_{i j}^{l}\right)^{2}+\left(X_{i j}^{m}\right)^{2}+\left(X_{i j}^{u}\right)^{2}\right]}}
\end{array}
$$

Step 4: Use fuzzy SWARA to compute the relative significant weight of each criterion.

Step 5: Gain the weighted normalized decision matrix by multiplying the fuzzy weights to normalized decision matrix, as presented in Eq. (4).

Step 6: Compute maximum value and total summation of each alternative, by using Eq. (18)

$$
\tilde{P}_{i}=\sum_{j=1}^{k} \tilde{Y}_{i j}
$$

Step 7: Calculate minimum value and total summation of each alternative, by using Eq. (19).

$$
\tilde{R}_{i}=\sum_{j=k+1}^{n} \tilde{Y}_{i j}
$$

Step 8: Determine minimum value of $\tilde{R}_{i}$ as $\tilde{R}_{\text {min }}$, by using Eq. (20).

$$
\tilde{R}_{\text {min }}=\min _{i} \tilde{R}_{i} ; i=1,2, \ldots, \mathrm{m}
$$

Step 9: Calculate the relative significance index $\left(\tilde{Q}_{i}\right)$ of each alternative, by using Eq. (21).

$$
\tilde{Q}_{i}=\tilde{P}_{i}+\frac{\tilde{R}_{\min } \sum_{i=1}^{m} \tilde{R}_{i}}{\tilde{R}_{i} \sum_{i=1}^{m} \frac{\tilde{R}_{m i n}}{\tilde{R}_{i}}} \quad ; i=1,2, \ldots, m
$$

Step 10: Convert the achieved $\tilde{Q}_{i}$ to non-fuzzy $\left(Q_{i}^{\text {non }}\right)$ (Fouladgar et al., 2012), as in Eq. (22).

$$
Q_{i}^{\text {non }}=\frac{\left(Q_{i}^{u}-Q_{i}^{l}\right)+\left(Q_{i}^{m}-Q_{i}^{l}\right)}{3}+\left(Q_{i}^{l}\right)
$$

Step 11: Select the optimal alternative by Eq. (23) based on the preference of the maximum weight of alternatives. 


$$
{ }^{242}=\max _{i} Q_{i}^{\text {non }} ; i=1,2, \ldots, m
$$

Step 12: Compute the percentage index $\left(N_{i}\right)$ by Eq. (24), and numbers will become de-fuzzy.

$$
N_{i}=\frac{Q_{i}^{\text {non }}}{Q_{\max }^{\text {non }}} \times 100 \% ; i=1,2, \ldots, m
$$

where $Q_{i}^{\text {non }}$ represents the non-fuzzy relative significant for each alternative and $Q_{\max }^{\text {non }}$ is value of the optimal alternative. Based on $N_{i}$, the rankings of alternatives are in descending order of expected significance. Then the higher value of $N_{i}$ represents the ideal alternative.

\section{Proposed research framework}

This research proposes a framework of potential supplier selection for VMI in healthcare by integrating three approaches of MCDM, i.e., Fuzzy Delphi, Fuzzy SWARA and Fuzzy COPRAS. This framework comprises of four phases, i. e., (i) extracting the supplier evaluation criteria from extensive literature review, (ii) screening the appropriate evaluation criteria by applying Fuzzy Delphi, (iii) determining the relative importance weights of evaluation criteria by employing Fuzzy SWARA, and (iv) ranking the potential suppliers' performance and selecting the best one by using Fuzzy COPRAS, as illustrated in Fig. 3.

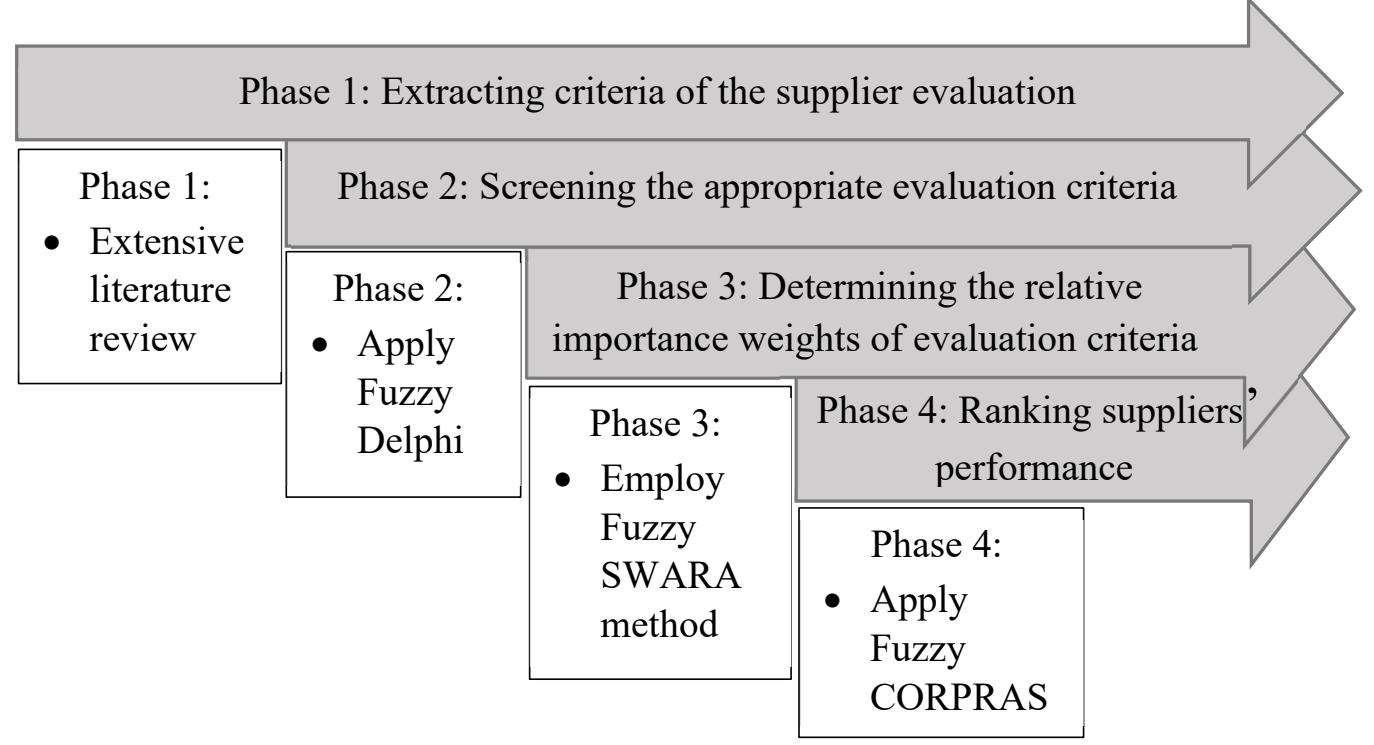

Fig. 3. Research framework for supplier selection on VMI in healthcare

\section{Problem Description}

The empirical case in this study is a local university hospital with capacity of 1,012 beds and full availability of main healthcare services as emergency service, intensive care units and operating rooms. It is located at Southern of Thailand and received high reputation from local citizens. However, this hospital has currently encountered an increasing cost of inventory, plenty of outdated stocks including high frequency of shortage inventory particular in high value pharmaceutical products. There are also some difficulties to forecast the desired inventory levels of patient needed. In order to solve these problems, the heads of warehouse management of hospital plans to adopt VMI as a pilot program for some critical pharmaceutical products such as saline solutions. They also require a decisive aid to select an appropriate pharmaceutical supplier to attend the program. By this approach, it needs a group of decision makers (DMs) which composed of six decision makers, i.e., DM1, DM2, DM3,.., DM6, in order to participate in three questionnaires (fuzzy Delphi, fuzzy SWARA and fuzzy COPRAS). These DMs have more than four-year experiences and specific knowledge in inventory management. They are also a head of warehouse, two managers from purchasing department and three pharmacists from 
pharmacy rooms. While, there are three candidate potential pharmaceutical suppliers, supposed namely Supplier A, Supplier B, Supplier C as alternatives. The qualification and information of DMs are displayed in Table A-1 and Table A-2 of Appendix A. Based on VMI supplier selection criteria from Table 1, all DMs participate in selecting the appropriated criteria, determining relative importance weight of selected criteria and evaluating such three candidate suppliers, respectively. The methodology for this research applies the Fuzzy Multi-Criteria approach in order to assist a group of DMs for selecting the best supplier for VMI project implementation.

\section{Results}

\subsection{Phase I: Extracting the suppliers' evaluation criteria}

As the results from the extensive literature review were presented in section 2.2, the fourteen evaluation criteria for VMI suppliers' evaluation were extracted as exhibited in Table 1.

\subsection{Phase II: Screening the appropriate evaluation criteria}

After obtaining the fourteen evaluation criteria, a group of decision maker provided the score values on both the most pessimistic value and the most optimistic value on each criteria. The data were then collected pass though questionnaire. Fuzzy Delphi approach as mentioned in Section 2.3.4 was applied to screen the appropriate evaluation criteria in accordance with the proposed of this study. Firstly, the average scores from all DMs were computed for the conservative and optimistic values of each criterion. Any value which outside two standard deviations is removed from consideration. The values of the minimum $\left(P_{L}^{i}\right)$, geometric mean $\left(P_{M}^{i}\right)$, and maximum $\left(P_{U}^{i}\right)$ of the conservative value, and the minimum $\left(O_{L}^{i}\right)$, geometric mean $\left(O_{M}^{i}\right)$, and maximum $\left(O_{U}^{i}\right)$ of the optimistic value were calculated and the result depicted in Table 4. Thereafter, the values of $M^{i}$ and $Z^{i}$ were calculated to verify the consistency of expert judgment. Subsequently, the consensus significant value $\left(G^{i}\right)$ for each criteria is calculated for screening the criteria by using either Eq.(6) or Eq. (7). Based on pareto 80/20 rule, the threshold value $(\tau)$ was set at 8.0. From Table 4 , since five evaluation criteria with consensus significant value were lower than such of threshold value $\left(G^{i}<\tau\right)$, they were rejected and the remaining of nine evaluation criteria ( $G^{i} \geq \tau$ ) were accepted, i. e., Part delivery performance, Institutional trust, Investment cost, Information sharing and exchanging, Supply chain process integration, Information technologies readiness, Supplier flexibility, Project implementation time and Risk/Reward sharing. While, two criteria in Table 4 are cost criteria, i.e., Investment cost and Project implementation time. And the remaining are benefit criteria. The proposed model of potential supplier selection for VMI was displayed in Fig. 4.

\section{Table 4}

The result of Fuzzy Delphi method

\begin{tabular}{|c|c|c|c|c|c|c|c|c|c|c|}
\hline \multirow[t]{2}{*}{ Measures } & \multicolumn{2}{|c|}{$\begin{array}{l}\text { Pessimistic } \\
\text { Value }\end{array}$} & \multicolumn{2}{|c|}{$\begin{array}{c}\text { Optimistic } \\
\text { Value }\end{array}$} & \multicolumn{2}{|c|}{ Geometric Mean } & \multirow[t]{2}{*}{$M^{i}-Z^{i}$} & \multirow{2}{*}{$\begin{array}{c}\text { Consensus } \\
\text { Value }\end{array}$} & \multirow[t]{2}{*}{ Decision } & \multirow[t]{2}{*}{$\begin{array}{l}\text { Type of } \\
\text { Criteria }\end{array}$} \\
\hline & $P_{L}$ & $P_{U}$ & $O_{L}$ & $O_{U}$ & $P_{M}$ & $P_{M}$ & & & & \\
\hline Past delivery performance & 7 & 8 & 8 & 9 & 7.65 & 8.41 & 1.35 & 8.03 & Accepted & Benefit \\
\hline Institutional trust & 6 & 8 & 9 & 10 & 7.45 & 9.31 & 3.55 & 8.38 & Accepted & Benefit \\
\hline Investment cost & 6 & 7 & 8 & 10 & 6.82 & 9.30 & 4.18 & 8.06 & Accepted & Cost \\
\hline Information sharing and exchanging & 7 & 8 & 9 & 10 & 7.82 & 9.65 & 3.18 & 8.74 & Accepted & Benefit \\
\hline Continuous improvement & 5 & 7 & 6 & 8 & 5.62 & 6.80 & 1.38 & 6.37 & Rejected & Benefit \\
\hline Supply Chain Process Integration & 6 & 8 & 8 & 9 & 7.63 & 8.49 & 1.37 & 8.06 & Accepted & Benefit \\
\hline Information technologies readiness & 7 & 8 & 9 & 10 & 7.82 & 8.63 & 3.18 & 8.23 & Accepted & Benefit \\
\hline Supplier flexibility & 6 & 8 & 8 & 9 & 7.63 & 8.46 & 1.37 & 8.04 & Accepted & Benefit \\
\hline Project implementation time & 6 & 7 & 8 & 10 & 6.65 & 9.47 & 4.35 & 8.06 & Accepted & Cost \\
\hline Devoted resources & 4 & 7 & 6 & 8 & 5.35 & 6.95 & 1.65 & 6.37 & Rejected & Benefit \\
\hline Spatial complexity & 4 & 6 & 5 & 8 & 4.75 & 6.43 & 2.25 & 5.53 & Rejected & Benefit \\
\hline Prior knowledge and experience & 5 & 6 & 6 & 7 & 5.48 & 6.65 & 1.52 & 6.06 & Rejected & Benefit \\
\hline Risk/Reward Sharing & 7 & 8 & 8 & 9 & 7.65 & 8.65 & 1.35 & 8.15 & Accepted & Benefit \\
\hline Reputation and position in industry & 4 & 6 & 5 & 7 & 4.93 & 5.77 & 1.07 & 5.42 & Rejected & Benefit \\
\hline
\end{tabular}

* Remark: Criteria with the consensus significance value $\left(G^{i}\right)$ lower than threshold value $(\tau)$ are rejected. 


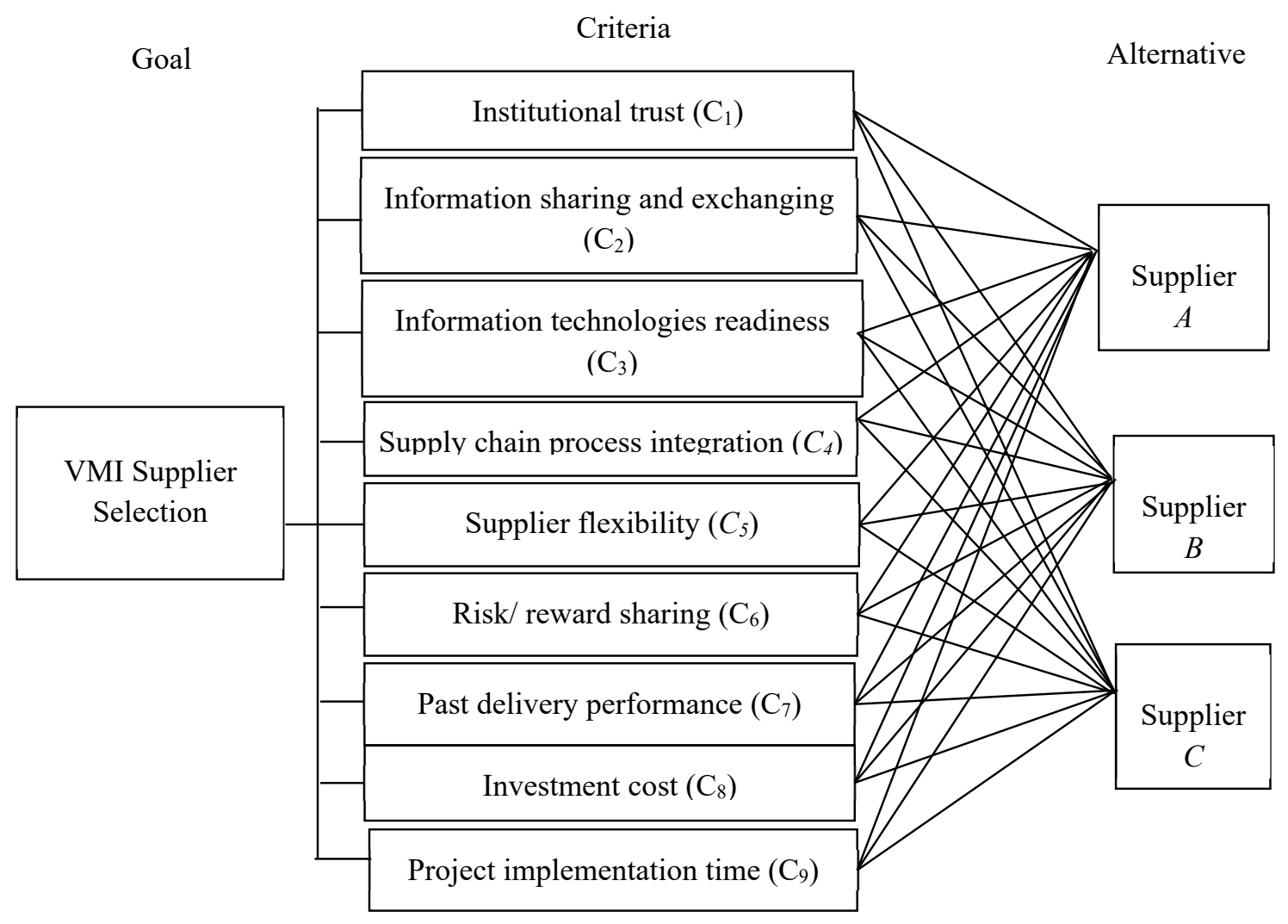

Fig. 4. The proposed model of VMI supplier selection

\subsection{Phase III: Determining the relative importance weights of evaluation}

Based on Table 2, the same group of decision makers expressed their judgments to determine the relative importance weight of each criterion in linguistic term as shown in Table A-1 of Appendix A. Then, the collected data from group of DMs were converted to the correspondence TFNs. Fuzzy SWARA method as described in Section 2.3.4 was employed to compute fuzzy weight for each criterion by using Eqs. (8)-(10), respectively. The fuzzy weight data of each criteria was transformed to non-fuzzy by Eq. (11). And the relative importance weight of each criteria was presented in Table 5.

According to Table 5, Institutional trust $\left(\mathrm{C}_{1}\right)$ is found to be the most important criteria with the relative weight of 0.440 , followed by Information sharing and exchanging $\left(\mathrm{C}_{2}\right)$ with the relative weight of 0.230 , and then Information technologies readiness $\left(\mathrm{C}_{3}\right)$ with the relative weight of 0.127 . While Part delivery performance $\left(\mathrm{C}_{7}\right)$, Investment cost $\left(\mathrm{C}_{8}\right)$ and Project implementation time $\left(\mathrm{C}_{9}\right)$ were the three smallest important criteria with the relative weights of $0.023,0.016$, and 0.012 , respectively. 
Table 5

The relative importance weight of main criteria with SWARA method

\begin{tabular}{|c|c|c|c|c|c|c|c|c|c|c|c|c|c|}
\hline \multirow{2}{*}{$\begin{array}{l}\text { Institutional } \\
\text { trust }\left(\mathrm{C}_{1}\right)\end{array}$} & \multicolumn{3}{|c|}{$\begin{array}{c}\text { Comparative } \\
\text { importance of average } \\
\text { value } \widetilde{S_{J}}\end{array}$} & \multicolumn{3}{|c|}{$\begin{array}{l}\text { Coefficient } \\
\widetilde{k}_{J}=\widetilde{S}_{J}+1\end{array}$} & \multicolumn{3}{|c|}{$\begin{array}{l}\text { Recalculated weight } \\
\qquad \widetilde{q}_{J}=\left(\widetilde{q}_{J}-1\right) / \tilde{k}_{j}\end{array}$} & \multicolumn{3}{|c|}{$\begin{array}{l}\text { Weight }\left(\widetilde{w}_{j}\right)= \\
\tilde{q}_{j} /\left(\sum_{k=1}^{n} \tilde{q}_{k}\right)\end{array}$} & \multirow{2}{*}{ 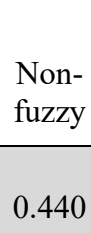 } \\
\hline & & & & 1 & 1 & 1 & 1 & 1 & 1 & 0.290 & 0.432 & 0.599 & \\
\hline $\begin{array}{l}\text { Information } \\
\text { sharing and } \\
\text { exchanging } \\
\left(\mathrm{C}_{2}\right)\end{array}$ & 0.400 & 0.775 & 1.500 & 1.400 & 1.775 & 2.500 & 0.400 & 0.564 & 0.714 & 0.207 & 0.240 & 0.243 & 0.230 \\
\hline $\begin{array}{l}\text { Information } \\
\text { Technology } \\
\text { readiness }\left(\mathrm{C}_{3}\right)\end{array}$ & 0.400 & 0.775 & 1.500 & 1.400 & 1.775 & 2.500 & 0.160 & 0.318 & 0.510 & 0.096 & 0.137 & 0.148 & 0.127 \\
\hline $\begin{array}{l}\text { Supply Chain } \\
\text { Process } \\
\text { Integration } \\
\left(\mathrm{C}_{4}\right)\end{array}$ & 0.400 & 0.775 & 1.500 & 1.400 & 1.775 & 2.500 & 0.064 & 0.179 & 0.364 & 0.038 & 0.077 & 0.106 & 0.074 \\
\hline $\begin{array}{l}\text { Supplier } \\
\text { flexibility } \\
\left(\mathrm{C}_{5}\right)\end{array}$ & 0.286 & 0.655 & 1.500 & 1.286 & 1.655 & 2.500 & 0.026 & 0.108 & 0.283 & 0.015 & 0.047 & 0.082 & 0.048 \\
\hline $\begin{array}{l}\text { Risk/ reward } \\
\text { sharing }\left(\mathrm{C}_{6}\right)\end{array}$ & 0.400 & 0.775 & 1.500 & 1.400 & 1.775 & 2.500 & 0.010 & 0.061 & 0.202 & 0.006 & 0.026 & 0.059 & 0.030 \\
\hline $\begin{array}{l}\text { Past delivery } \\
\text { performance } \\
\left(\mathrm{C}_{7}\right)\end{array}$ & 0.286 & 0.436 & 0.667 & 1.286 & 1.436 & 1.667 & 0.006 & 0.042 & 0.157 & 0.004 & 0.018 & 0.046 & 0.023 \\
\hline $\begin{array}{l}\text { Investment } \\
\text { cost }\left(\mathrm{C}_{8}\right)\end{array}$ & 0.286 & 0.655 & 1.500 & 1.286 & 1.655 & 2.500 & 0.002 & 0.026 & 0.122 & 0.001 & 0.011 & 0.036 & 0.016 \\
\hline $\begin{array}{l}\text { Project } \\
\text { implementat } \\
\text { ion time }\left(\mathrm{C}_{9}\right)\end{array}$ & 0.286 & 0.436 & 0.667 & 1.286 & 1.436 & 1.667 & 0.001 & 0.018 & 0.095 & 0.001 & 0.008 & 0.028 & 0.012 \\
\hline
\end{tabular}

\subsection{Phase IV: Ranking the potential suppliers' performance}

In this section, Fuzzy COPRAS procedure as presented in Section 2.3.5 was applied to appraisal and rank VMI performance Supplier A, Supplier B, and Supplier C. DMs participated to perform the rating of suppliers' performance by using linguistic terms in Table 3. The rating with respect to each criterion were resulted in Table A-3 of Appendix A. The fuzzy aggregated decision matrix was constructed by using Eqs. (13)-(14), as displayed in Table 6. Then, the normalize matrix was calculated by Eqs. (15)(17), as presented in Table 7. By using the fuzzy weights of each criterion from Fuzzy SWARA method, the weighted normalized fuzzy decision making matrix was obtained by Eq. (4) and shown in Table 8 . The ranking suppliers' performance was carried out by Eqs. (18)-(24), as exhibited in Table 9. Based on the percentage index $\left(N_{i}\right)$ in Table 9 , this study revealed that the raking of potential suppliers in descending order is identified as Supplier C $>$ Supplier B $>$ Supplier A, with $N_{i}$ values of $100 \%, 89.552 \%$, and $69.496 \%$, respectively. Therefore, Supplier C is the best alternative for VMI implementation. 
Table 6

Fuzzy aggregated decision matrix between alternatives and criteria

\begin{tabular}{|c|c|c|c|c|}
\hline & & $\begin{array}{c}\text { Supplier } \\
\text { A }\end{array}$ & $\begin{array}{c}\text { Supplier } \\
\text { B }\end{array}$ & $\underset{\text { C }}{\text { Supplier }}$ \\
\hline \multirow{3}{*}{$\begin{array}{l}\text { Institutional } \\
\text { trust }\left(\mathrm{C}_{1}\right)\end{array}$} & 1 & 0.333 & 0.208 & 0.542 \\
\hline & $\mathrm{m}$ & 0.527 & 0.384 & 0.736 \\
\hline & $\mathrm{u}$ & 0.833 & 0.708 & 1 \\
\hline \multirow{3}{*}{$\begin{array}{l}\text { Information } \\
\text { sharing and } \\
\text { exchanging } \\
\left(\mathrm{C}_{2}\right)\end{array}$} & 1 & 0.25 & 0.5 & 0.458 \\
\hline & $\mathrm{m}$ & 0.433 & 0.692 & 0.633 \\
\hline & $\mathrm{u}$ & 0.75 & 0.958 & 0.875 \\
\hline \multirow{3}{*}{$\begin{array}{l}\text { Information } \\
\text { Technology } \\
\text { readiness }\left(\mathrm{C}_{3}\right)\end{array}$} & 1 & 0.208 & 0.333 & 0.5 \\
\hline & $\mathrm{m}$ & 0.384 & 0.527 & 0.677 \\
\hline & $\mathrm{u}$ & 0.708 & 0.833 & 0.917 \\
\hline \multirow{3}{*}{$\begin{array}{l}\text { Supply Chain } \\
\text { Process } \\
\text { Integration } \\
\left(\mathrm{C}_{4}\right)\end{array}$} & 1 & 0.208 & 0.333 & 0.458 \\
\hline & $\mathrm{m}$ & 0.384 & 0.527 & 0.648 \\
\hline & $\mathrm{u}$ & 0.708 & 0.833 & 0.917 \\
\hline \multirow{3}{*}{$\begin{array}{l}\text { Supplier } \\
\text { flexibility }\left(\mathrm{C}_{5}\right)\end{array}$} & 1 & 0.5 & 0.625 & 0.458 \\
\hline & $\mathrm{m}$ & 0.707 & 0.791 & 0.633 \\
\hline & $\mathrm{u}$ & 1 & 1 & 0.875 \\
\hline \multirow{3}{*}{$\begin{array}{l}\text { Risk/ reward } \\
\text { sharing }\left(\mathrm{C}_{6}\right)\end{array}$} & 1 & 0.042 & 0.25 & 0.042 \\
\hline & $\mathrm{m}$ & 0.125 & 0.433 & 0.132 \\
\hline & $\mathrm{u}$ & 0.375 & 0.75 & 0.417 \\
\hline \multirow{3}{*}{$\begin{array}{l}\text { Past delivery } \\
\text { performance } \\
\left(\mathrm{C}_{7}\right)\end{array}$} & 1 & 0.333 & 0.25 & 0.333 \\
\hline & $\mathrm{m}$ & 0.527 & 0.433 & 0.527 \\
\hline & $\mathrm{u}$ & 0.833 & 0.75 & 0.833 \\
\hline \multirow{3}{*}{$\begin{array}{l}\text { Investment } \\
\text { cost }\left(\mathrm{C}_{8}\right)\end{array}$} & 1 & 0.542 & 0.333 & 0.167 \\
\hline & $\mathrm{m}$ & 0.72 & 0.527 & 0.333 \\
\hline & $\mathrm{u}$ & 0.958 & 0.833 & 0.667 \\
\hline \multirow{3}{*}{$\begin{array}{l}\text { Project } \\
\text { implementation } \\
\text { time }\left(\mathrm{C}_{9}\right)\end{array}$} & 1 & 0.458 & 0.167 & 0.125 \\
\hline & $\mathrm{m}$ & 0.648 & 0.333 & 0.28 \\
\hline & $\mathrm{u}$ & 0.917 & 0.667 & 0.625 \\
\hline
\end{tabular}

Table 7

Normalized fuzzy aggregated decision matrix

\begin{tabular}{|c|c|c|c|c|}
\hline & & $\begin{array}{c}\text { Supplier } \\
\text { A }\end{array}$ & $\begin{array}{c}\text { Supplier } \\
\text { B }\end{array}$ & $\begin{array}{c}\text { Supplier } \\
\text { C }\end{array}$ \\
\hline \multirow{3}{*}{$\begin{array}{l}\text { Institutional } \\
\text { trust }\left(\mathrm{C}_{1}\right)\end{array}$} & 1 & 0.175 & 0.11 & 0.285 \\
\hline & $\mathrm{m}$ & 0.277 & 0.202 & 0.387 \\
\hline & $\mathrm{u}$ & 0.439 & 0.373 & 0.526 \\
\hline \multirow{3}{*}{$\begin{array}{l}\text { Information } \\
\text { sharing and } \\
\text { exchanging } \\
\left(\mathrm{C}_{2}\right)\end{array}$} & 1 & 0.128 & 0.255 & 0.234 \\
\hline & $\mathrm{m}$ & 0.221 & 0.353 & 0.323 \\
\hline & $\mathrm{u}$ & 0.383 & 0.489 & 0.447 \\
\hline \multirow{3}{*}{$\begin{array}{l}\text { Information } \\
\text { Technology } \\
\text { readiness }\left(C_{3}\right)\end{array}$} & 1 & 0.114 & 0.183 & 0.274 \\
\hline & $\mathrm{m}$ & 0.211 & 0.289 & 0.371 \\
\hline & $\mathrm{u}$ & 0.388 & 0.457 & 0.503 \\
\hline \multirow{3}{*}{$\begin{array}{l}\text { Supply Chain } \\
\text { Process } \\
\text { Integration } \\
\left(\mathrm{C}_{4}\right)\end{array}$} & 1 & 0.116 & 0.185 & 0.254 \\
\hline & $\mathrm{m}$ & 0.213 & 0.293 & 0.36 \\
\hline & $\mathrm{u}$ & 0.393 & 0.462 & 0.509 \\
\hline \multirow{3}{*}{$\begin{array}{l}\text { Supplier } \\
\text { flexibility }\left(\mathrm{C}_{5}\right)\end{array}$} & 1 & 0.22 & 0.276 & 0.202 \\
\hline & $\mathrm{m}$ & 0.312 & 0.349 & 0.279 \\
\hline & $\mathrm{u}$ & 0.441 & 0.441 & 0.386 \\
\hline \multirow{3}{*}{$\begin{array}{l}\text { Risk/ reward } \\
\text { sharing }\left(C_{6}\right)\end{array}$} & 1 & 0.039 & 0.232 & 0.039 \\
\hline & $\mathrm{m}$ & 0.116 & 0.401 & 0.122 \\
\hline & $\mathrm{u}$ & 0.348 & 0.695 & 0.386 \\
\hline \multirow{3}{*}{$\begin{array}{l}\text { Past delivery } \\
\text { performance } \\
\left(\mathrm{C}_{7}\right)\end{array}$} & 1 & 0.193 & 0.145 & 0.193 \\
\hline & $\mathrm{m}$ & 0.305 & 0.251 & 0.305 \\
\hline & $\mathrm{u}$ & 0.483 & 0.435 & 0.483 \\
\hline \multirow{3}{*}{$\begin{array}{l}\text { Investment } \\
\text { cost }\left(C_{8}\right)\end{array}$} & 1 & 0.294 & 0.181 & 0.09 \\
\hline & $\mathrm{m}$ & 0.391 & 0.286 & 0.181 \\
\hline & $\mathrm{u}$ & 0.52 & 0.452 & 0.362 \\
\hline \multirow{3}{*}{$\begin{array}{l}\text { Project } \\
\text { implementation } \\
\text { time }\left(\mathrm{C}_{9}\right)\end{array}$} & 1 & 0.288 & 0.105 & 0.078 \\
\hline & $\mathrm{m}$ & 0.407 & 0.209 & 0.175 \\
\hline & $\mathrm{u}$ & 0.575 & 0.418 & 0.392 \\
\hline
\end{tabular}


Table 8

The weighted normalized fuzzy decision making matrix

\begin{tabular}{|c|c|c|c|c|}
\hline & & Supplier A & Supplier B & Supplier C \\
\hline \multirow[t]{3}{*}{ Institutional trust $\left(\mathrm{C}_{1}\right)$} & 1 & 0.05 & 0.03 & 0.08 \\
\hline & $\mathrm{m}$ & 0.12 & 0.09 & 0.17 \\
\hline & $\mathrm{u}$ & 0.26 & 0.22 & 0.32 \\
\hline \multirow[t]{3}{*}{ Information sharing and exchanging $\left(\mathrm{C}_{2}\right)$} & 1 & 0.03 & 0.05 & 0.05 \\
\hline & $\mathrm{m}$ & 0.05 & 0.08 & 0.08 \\
\hline & $\mathrm{u}$ & 0.09 & 0.12 & 0.11 \\
\hline \multirow[t]{3}{*}{ Information Technology readiness $\left(\mathrm{C}_{3}\right)$} & 1 & 0.01 & 0.02 & 0.03 \\
\hline & $\mathrm{m}$ & 0.02 & 0.03 & 0.04 \\
\hline & $\mathrm{u}$ & 0.06 & 0.07 & 0.07 \\
\hline \multirow[t]{3}{*}{ Supply Chain Process Integration $\left(\mathrm{C}_{4}\right)$} & 1 & 0 & 0.01 & 0.01 \\
\hline & $\mathrm{m}$ & 0.02 & 0.02 & 0.03 \\
\hline & $\mathrm{u}$ & 0.04 & 0.05 & 0.05 \\
\hline \multirow[t]{3}{*}{ Supplier flexibility $\left(\mathrm{C}_{5}\right)$} & 1 & 0 & 0 & 0 \\
\hline & $\mathrm{m}$ & 0.01 & 0.02 & 0.01 \\
\hline & $\mathrm{u}$ & 0.04 & 0.04 & 0.03 \\
\hline \multirow[t]{3}{*}{ Risk/ reward sharing $\left(\mathrm{C}_{6}\right)$} & 1 & 0 & 0 & 0 \\
\hline & $\mathrm{m}$ & 0 & 0.01 & 0 \\
\hline & $\mathrm{u}$ & 0.02 & 0.04 & 0.02 \\
\hline \multirow[t]{3}{*}{ Past delivery performance $\left(\mathrm{C}_{7}\right)$} & 1 & 0 & 0 & 0 \\
\hline & $\mathrm{m}$ & 0.01 & 0 & 0.01 \\
\hline & $\mathrm{u}$ & 0.02 & 0.02 & 0.02 \\
\hline \multirow[t]{3}{*}{ Investment cost $\left(\mathrm{C}_{8}\right)$} & 1 & 0 & 0 & 0 \\
\hline & $\mathrm{m}$ & 0 & 0 & 0 \\
\hline & $\mathrm{u}$ & 0.02 & 0.02 & 0.01 \\
\hline \multirow[t]{3}{*}{ Project implementation time $\left(\mathrm{C}_{9}\right)$} & 1 & 0 & 0 & 0 \\
\hline & $\mathrm{m}$ & 0 & 0 & 0 \\
\hline & $\mathrm{u}$ & 0.02 & 0.01 & 0.01 \\
\hline
\end{tabular}

Table 9

Final results and ranking with Fuzzy COPRAS

\begin{tabular}{|c|c|c|c|c|c|c|c|c|c|c|c|c|}
\hline & \multicolumn{3}{|c|}{$\tilde{P}_{i}$} & \multicolumn{3}{|c|}{$\tilde{R}_{i}$} & \multicolumn{3}{|c|}{$\tilde{Q}_{i}$} & \multirow{2}{*}{$\begin{array}{c}\text { Non- } \\
\text { fuzzy } \\
\left(Q_{i}^{\text {non }}\right)\end{array}$} & \multirow[b]{2}{*}{$N_{i}$} & \multirow[b]{2}{*}{ Rank } \\
\hline & $l$ & $m$ & $u$ & $l$ & $m$ & $u$ & $l$ & $m$ & $u$ & & & \\
\hline $\begin{array}{c}\text { Supplier } \\
\text { A }\end{array}$ & 0.071 & 0.183 & 0.453 & 0.027 & 0.059 & 0.115 & 0.133 & 0.281 & 0.595 & 0.336 & 89.552 & 2 \\
\hline $\begin{array}{c}\text { Supplier } \\
\text { B }\end{array}$ & 0.062 & 0.171 & 0.444 & 0.053 & 0.089 & 0.139 & 0.094 & 0.127 & 0.562 & 0.261 & 69.496 & 3 \\
\hline $\begin{array}{c}\text { Supplier } \\
\text { C } \\
\end{array}$ & 0.123 & 0.253 & 0.521 & 0.049 & 0.083 & 0.131 & 0.158 & 0.322 & 0.646 & 0.376 & 100.000 & 1 \\
\hline
\end{tabular}




\section{Sensitivity Analysis}

In this section, the sensitivity analysis was carried out to test the stability of the proposed framework by exchanging the weight of each criterion with such of another criterion. Then, there were 36 different formulated scenarios of the interchanging, as illustrated in Table A-4 of Appendix A. For example, scenario $\left(S_{1}\right)$ is defined as $C_{1}-C_{2}$ meaning the weights of criterion $C_{1}$ and $C_{2}$ have changed, while others remain unchanged. In this study, the different 36 scenarios are performed by presenting various names as follows: $\mathrm{C}_{1}-\mathrm{C}_{2}, \mathrm{C}_{1}-\mathrm{C}_{3}, \mathrm{C}_{1}-\mathrm{C}_{4}, \mathrm{C}_{1}-\mathrm{C}_{5}, \mathrm{C}_{1}-\mathrm{C}_{6}, \mathrm{C}_{1}-\mathrm{C}_{7}, \mathrm{C}_{1}-\mathrm{C}_{8}, \mathrm{C}_{1}-\mathrm{C}_{9} \ldots \mathrm{C}_{8}-\mathrm{C}_{9}$. In each scenario, nonfuzzy relative significant value $\left(Q_{i}^{\text {non }}\right)$ and the range of percentage $\left(N_{i}\right)$ for each supplier were calculated. From Table A- 4, supplier $\mathrm{C}$ has the first ranking for all scenarios, with all $N_{i}$ values of $100 \%$, as illustrated by Figs. 5-6. While the ranking of supplier A is almost superior to supplier B, except scenario 1, 2, and 3. Based on this analysis, it can be concluded that the proposed decision making framework has been validated and it is a reliable tool for the hospital case study to select a potential supplier for VMI implementation.

\section{Discussion and managerial implication}

Based on research findings, there are some managerial implications addressed and comparable to prior studies. In terms of relative importance weight, this research has revealed that the most important evaluation criteria were Institutional trust followed by Information sharing and exchanging, and Information technologies readiness, respectively. Considering the institutional trust, the finding is consistent with Singh and Teng (2016) to affirm that institutional trust is the most crucial factor for a successful VMI collaboration. It also implies that hospital managers who need to select suppliers to participate in VMI initiative program should foster higher level of trust among supply chain partners. Lacking of institutional trust between them would be an obstacle to initiate VMI collaboration (Abdallah et al., 2017). In view of information sharing and exchanging information, the finding from this study is in line with several prior studies including Krichanchai and MacCarthy (2017) which pointed out that information sharing between hospital and suppliers is the essential in VMI collaboration. Hence, the prerequisite of VMI implementation requires an information sharing process across the supply chain by adopting an information technology. As described by Raweewan and Ferrell (2018), information sharing between VMI partners including demand forecasts, inventory level, production planning and delivery schedule are the key components for the success of VMI implementation. This study advises that hospital managers have to take the effective two- way information sharing and exchanging between both parties into consideration when selecting the potential supplier. This is considered as a potentially useful case study for organizations involved in hospital industry. Since, in Thailand, each player in healthcare sector has mostly developed his/her own information system resulting to lack of sharing or communicating with its partners. For information technologies readiness, the result of this study supports the prior research in this stream including Falasca et al. (2016) stated that VMI implementation can be achieved through robust information technologies. The effective information technology is a vital part for the success of VMI implementation (García-Villarreal et al., 2019). VMI utilizes information technologies to transfer real time data in order to render optimal decision on the replenishment schedule (Liu et al., 2017). Ultimately, this implies that, for the potential supplier selection in VMI usage, the hospital managers also need to evaluate suppliers' information technologies readiness before VMI can be initiated. 


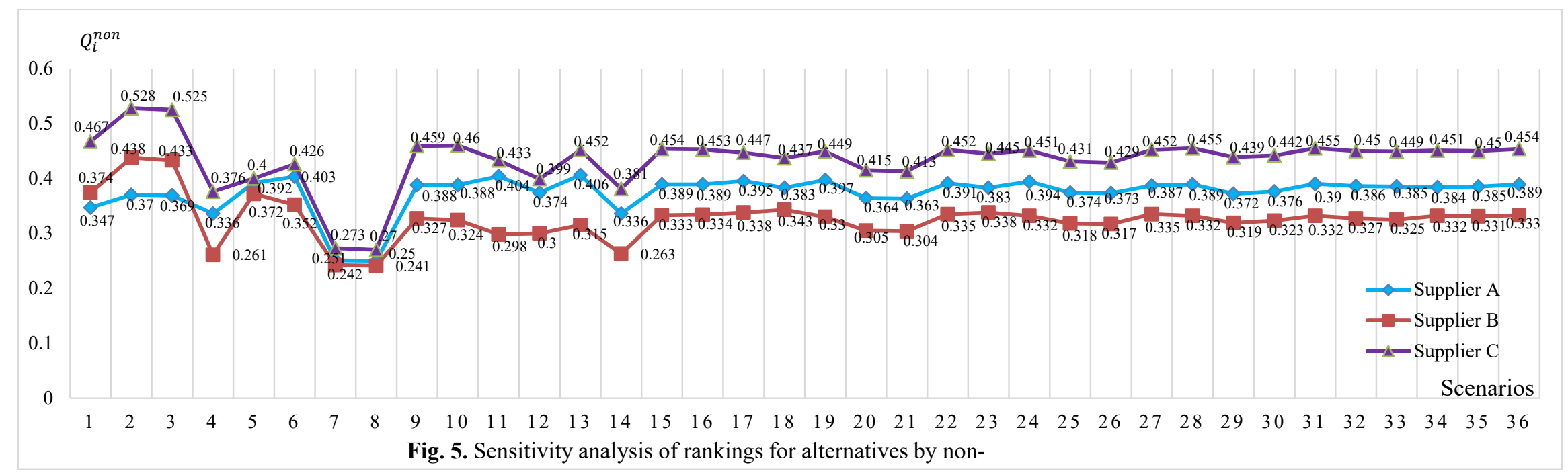

$\mathrm{N}_{\mathrm{i}}$

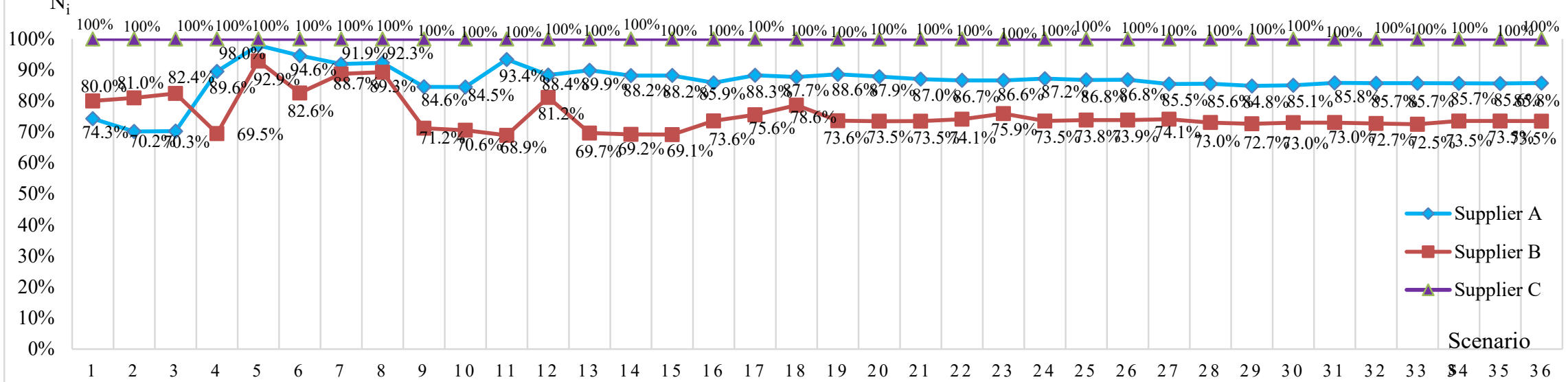

Fig. 6. Sensitivity analysis of rankings for alternatives $\mathrm{N}_{\mathrm{i}}$ 


\section{Conclusion}

Many manufacturing and service organizations are currently seeking new strategies to reduce not only inventory cost but also to enhance the efficiency of supplier collaboration. In this study, supplier model selection for VMI in healthcare offers a set of criteria for selecting appropriated supplier. Notwithstanding, due to the complicated revolved with inventory management of hospitals activities, many hospital managements tend to handle their own systems rather than sharing information among their partners. Such caused the inefficiency of supplier collaboration and rising overall cost among parties. For this reason, the effective supplier selection of the VMI process in hospitals has become an interesting research problem.

Regarding to many prior research, the VMI implementation both in manufacturing and healthcare sector can generate benefits through sustainable VMI process. However, in terms of supplier selection for VMI in healthcare sector, there has been less attention paid to such studies. This study has proposed a four-phase comprehensive framework for selecting the best potential suppliers for VMI collaboration in healthcare organization by using a comprehensive MCDM framework. The research has also been applied in one of famous public hospitals in Thailand as a case study. Based on the extensive literature survey and the validation of a decision maker group, the appropriated criteria for VMI supplier selection has been determined. The integration of Fuzzy MCDM approach has been deployed by incorporating Fuzzy Delphi, Fuzzy SWARA and Fuzzy COPRAS to tackle a problem of vagueness and uncertainty of human judgment. A fuzzy SWARA approach was used to weight the criteria evaluation, and a developed fuzzy COPRAS was applied to rank and select the best appropriated supplier in the presence criteria. Furthermore, the results and discussions are examined and followed by managerial implications. The study also offers directions for future research. First, this proposed model can be applied in other industries or similar supplier selection. Next, future research can extend the different approach of other MCDM such as PROMETHEE and TODIM under changed scenarios.

\section{References}

Abbady, M.A.S., Akkaya, M., \& Sari, A. (2019). Big data governance, dynamic capability and decision-making effectivenes: Fuzzy sets approach. Decision Science Letters, 8(4), 429-440.

Abdallah, A. B., Abdullah, M. I., \& Saleh, F. M. (2017). The effect of trust with suppliers on hospital supply chain performance. The mediating role of supplier integration. 24(3), 694-715.

Bhakoo, V., Singh, P. and Sohal, A. (2012). Collaborative management of inventory in Australian hospital supply chains: practices and issues. Supply Chain Management: An International Journal, 17(2), 217-230.

Chang, D.Y. (1996). Application of the extent analysis method on fuzzy AHP. European Journal of Operational Research, 95(3), 649-655.

Chatterjee, N.C., \& Bose, G.K. (2013). Selection of vendors for wind farm under fuzzy MCDM environment. International Journal of Industrial Engineering Computations, 4(4), 535-546.

Chen, D. Q., Preston, D. S. \& Xia, W. (2013). Enhancing hospital supply chain performance: a relational view and empirical test. Journal of Operations Management, 31(6), 391-408.

Classen, M. J. T., Weele, A. J. V. \& Raaij, E. M. V. (2008). Performance outcomes and success factors of vendor managed inventory (VMI). Supply Chain Management: An International Journal, 13(6), 406-414.

Danese, P. (2007). Designing CPFR collaborations: insights from seven case studies. International Journal of Operations \& Production Management, 27(2), 181-204.

De Vries, J. (2011). The shaping of inventory systems in health services: A stakeholder analysis. International Journal of Production Economics, 118(1), 136-145.

Dong, Y., \& Xu, K. (2002). A supply chain model of vendor managed inventory. Transportation research part E: logistics and transportation review, 38(2), 75-95. 
Dong, Y., Xu, K. \& Dresner, M. (2007). Environmental determinants of VMI adoption: an exploratory analysis. Transportation Research Part E: Logistics and Transportation Review, 43(4), 355-369.

Eghbali-Zarch, M., Tavakkoli-Moghaddaam, R., Esfahanian, F., \& Sepehri, M.M.(2018). Pharmacological therapy selection of type 2 diabetes based on the SWARA and method MULTIMOORA methods under a fuzzy environment. Artificial Intelligence in Medicine, 87, 20-33. https://doi.org/10.1016./j.artmed.2018.03.003.

Falasca, M., John, F. Kros, \& Nadler, S. S. (2016). Performance outcomes and success factors of industrial vending solutions. International Journal of Operations \& Production Management, 36(10), 1359-1381.

Flynn, B.B., Koufteros, X., \& Lu, G. (2016). On theory in supply chain uncertainty and its implications for supply chain integration. Journal of Supply Chain Management, 52(3), 3-27.

Fouladgar, M. M., Chamzini, A. Y., Zavadskas, E.K., \& Moini, S. H. H. (2012). A new hybrid model for evaluating the working strategies: case study of construction company, Technological and Economic Development of Economy, 18(1), 164-188.

García-Villarreal, E., Bhamra, R., \& Schoenheit, M. (2019). Critical success factors of medical technology supply chains. Production Planning \& Control, 30(9), 716-735.

Guimarães, C. M., Carvalho, J. C. \& Maia, A. (2013). Vendor managed inventory (VMI): Evidences from lean deployment in healthcare. Strategic Outsourcing: An International Journal, 6(1), 8-24.

Hui, S. (2010). Research on supply management in hospital based on VMI. $17^{\text {th }}$ International Conference on Industrial Engineering and Engineering Management, IEEE. On 29-31 Oct, 2010. Xiamen, China. https://doi.org/10.1109/ICIEEM.2010.5646000.

Jayaram, J., Nicolae, M. \& Xu, Kefeng. (2011). The direct and contingency effects of supplier coordination and customer coordination on quality and flexibility performance. International Journal of Production Research, 49(1), 59-85.

Kaklauskas, A., Zavadskas, E.K., Raslanas, S., Ginevicius, R., Komka, A., \& Malinauskas, P. (2006). Selection of low-e windows in retrofit of public buildings by applying multiple criteria method CORPAS: a Lithuanian case, Energy and Buildings, 38(5), 454-462.

Kannan, D., Jabbour, A. B. L. D. S., \& Jabbour, C. J. C. (2014). Selecting green suppliers based on GSCM practices: Using Fuzzy TOPSIS applied to a Brazilian electronics company. European Journal of Operational Research, 233(2), 432-447.

Keršullene, V., Zavadskas, E.K., \& Turskis, Z. (2010). Selection of rational dispute resolution method by applying new step-wise weight assessment ratio analysis (Swara). Journal of Business Econonmics and Management, 11(2), 243-258.

Kim, D. (2005). An integrated supply chain management system: A case study in healthcare sector, International Conference on Electronic Commerce and Web Technologies, EC-Web, August, 2005: E-Commerce and Web Technologies, 3590, pp. 218-227.

Krichanchai, S. \& MacCarthy, B. L. (2017). The adoption of vendor managed inventory for hospital pharmaceutical supply. International Journal of Logistics Management, 28(3), 755-780.

Kros, J. F., Kirchoff, J. F., \& Falasca, M. (2019). The impact of buyer-supplier relationship quality and information management on industrial vending machine benefits in the healthcare industry. Journal of Purchasing and Supply Management, 25(3), https://doi.org/10.1016/j.pursup.2018.06.005.

Kwon, I.W.G., Kim, S.H., \& Martin, D.G. (2016). Healthcare supply chain management; strategic areas for quality and financial improvement. Technological Forecasting \& Social Change, 113, 422-428. https://doi.org/10.1016/j.techfore.2016.07.014.

Lee, A.H.I., Wang, W., \& Lin, T. (2010). An evaluation framework for technology transfer of new equipment in high technology industry. Technological Forecasting and Social Change, 77(1), 135-150.

Liu, M., Zhang, Z. \& Zhang, D. (2017). Logistics planning for hospital pharmacy trusteeship under a hybrid of uncertainties. Transportation Research Part E: Logistics and Transportation Review, 101, 201-215. https://doi.org/10.1016/j.tre.2017.02.006.

Mardani, A., Nilashi, M., Zakuan, N., Loganathan, N., Soheilirad, S., \& Saman, M.Z.M. (2017). A systematic review and meta-Analysis of SWARA and WASPAS methods: theory and applications with recent fuzzy developments. Applied Soft Computing, 57, 265-292. https://doi.org/10.1016/j.asoc.2017.03.045. 
Matopoulos, A. \& Michailidou, L. (2013). Implementing collaborative practices in the healthcare supply chain: insights into hospital-vendor operations. International Journal of Logistics Systems and Management, $15(2 / 3), 288-303$.

Moons, K., Waeyenbergh, G., \& Pintelon, L. (2019). Measuring the logistics performance of internal hospital supply chains - A literature study. Omega, 82, 205-217. https://doi.org/10.1016/j.omega.2018.01.007.

Naeij, J., \& Shavandi, H. (2010). An optimal lot sizing and pricing in two echelon supply chain. International Journal of Industrial Engineering Computations, 1(1), 11-32.

Ngampunvetchakul, S. (2014). Hospital warehouse and inventory management: a case study of VMI implementation. A thesis submitted in partial fulfillment of the requirements for the degree of master of engineering (Industrial engineering), Faculty of graduate studies, Mahidol University.

Niemsakul, J., Islam, S.M.N., Singkarin, D., Somboonwiwat, T. (2018). Cost-benefit sharing in healthcare supply chain collaboration. International Journal of Logistics Systems and Management, 30(3), 406-420.

Niknamfar, A. H. (2015). Multi-objective production-distribution planning based on vendor-managed inventory strategy in a supply chain. Industrial Management \& Data Systems, 115(6), 1086-1112.

Persin, S.(2018). An integrated fuzzy SWARA and fuzzy AD approach for outsourcing provider selection. Journal of Manufacturing Technology Management, 30(2), 531-552.

Raad, N.G., Shirazi, M.A. \& Ghodsypour, S.H. (2020). Selecting a portfolio of projects considering both optimization and balance of sub-portfolios. Journal of Project Management, 5(1), 1-16.

Ramanathan, U. (2012). Supply chain collaboration for improved forecast accuracy of promotional sales. International Journal of Operations \& Production Management, 32(6), 676-695.

Raweewan, M., \& Ferrell, W. G. Jr. (2018). Information sharing in supply chain collaboration. Computers \& Industrial Engineering, 126, 269-281. https://doi.org/10.1016/j.cie.2018.09.042.

Savasaneril, S., \& Erkip, N. (2010). An analysis of manufacturer benefits under vendor managed systems. IIE Transactions. 42(7), 455-477.

Schitea, D., Deveci, M., Iordache, M., Bigili, Kürsad, B., Akyurt, I.Z. \& Iordache, I. (2019). Hydrogen mobility roll-up site selection using intuitionistic fuzzy sets based WASPAS, COPRAS and EDAS. International Journal of Hydrogen Energy, 44, 8585-8600. https://doi.org/10.1016/j.ijhydene.2019.02.011.

Shih, S. C., Rivers, P. A., \& Hsu, S.H.Y. (2009). Strategic information technology alliances for effective healthcare supply chain management. Health Services Management Research, 22(3), 140-150.

Shou, Y., Li, Y., Park, Y., \& Kang, M. (2018). Supply chain integration and operational performance: The contingency effects of production systems. Journal of Purchasing and Supply Management, 24, 352-360. https://doi.org/10.1016/j.pursup.2017.11.004.

Singh, A. \& Teng, J.T.C. (2016). Enhancing supply chain outcomes through Information Technology and Trust. Computers in Human Behavior, 54, 290-300. https://doi.org/10.1016/j.chb.2015.07.051.

Singh, R.K. (2013). Analyzing the factors for VMI implementaion: A framework. Global Business Review, 14(1), 169-186. SAGE.

Somsuk, N., \& Laosirihongthong, T. (2017). Prioritization of applicable drivers for green supply chain management implementation toward sustainability in Thailand. International Journal of Sustainable Development \& World Ecology, 24(2), 175-191.

Sui, A. (2010). A reinforcement learning approach for inventory replenishment in vendor-managed inventory systems with consignment inventory. Engineering Management Journal, 22(4), 44-53.

Sumrit, D. (2019). A multi-criteria decision making model for readiness assessment of vendor managed inventory in healthcare. International Journal of Management and Decision Making, 18(1), https://doi.org/10.1504/IJMDM.2019.10021559.

Tony, A., \& Zamalo, E., (2005). From a traditional replenishment system of vendor managed inventory: a case study from the household electrical appliances sector. International Journal of Production Economics, 96(1), 63-79.

Vigtil, A. (2007). Information exchange in vendor managed inventory. International Journal of Physical Distribution and Logistics Management, 37(2), 131-147. 
Volland, J., Fuegener, A., Schoenfelder, J., \& Brunner, J.O. (2017). Material logistics in hospitals: a literature review. Omega, 69, 82-101. https://doi.org/10.1016/j.omega.2016.08.004.

Wang, X. (2015). A comprehensive decision making model for the evaluation of green operations initiatives. Technological Forecasting and Social Change, 95, 191-207. https://doi.org/0000-0002-5788-9387.

Watt, D. J., Kayis, B. \& Willey, K. (2010). The relative importance of tender evaluation and contractor selection criteria. International Journal of Project Management, 28(1), 51-60.

Wei, W.L., \& Chang, W.C. (2008). Analytic network process-based model for selecting an optimal product design solution with zero-one goal programming. Journal of Engineering Design, 19(1), 15-44.

Weraikat, D., Zanjani, M.K., \& Lehoux, N. (2019). Improving sustainability in a two-level pharmaceutical supply chain through Vendor-Managed Inventory System. Operations Research for Health Care, 21, 44-55. https://doi.org/10.1016/j.orhc.2019.04.004.

Yang, Z., Jiang, Y., \& Xie, E. (2019). Buyer-supplier relational strength and buying firm's marketing capability: An outside-in perspective. Industrial Marketing Management. https://doi.org/10.1016./j.indmarman.2019.03.009.

Yao, Y., Evers, P. T., \& Dresner, M. E. (2007). Supply chain integration in vendor managed inventory. Decision support systems, 43(2), 663-674.

Yazdani, M., Gonzalez, E.D.R.S., \& Chatterjee, P. (2019). A multi-criteria decision-making framework for agriculture supply chain risk management under a circular economy context. Agriculture supply chain risk management. https://doi.org/10.1108/MD-10-2018-1088.

Yu, H., Tang, L., Xu, Y., \& Wang, Y. (2015). How much does VMI better than RMI in a global environment? International Journal of Production Economics, 170, 268-274. https://doi.org/10.1016/j.ijpe.2015.10.004.

Zadeh, L. A. (1965). Fuzzy Sets. Information and control, 8(3), 338-353.

Zarbakhshnia, N., Soleimani, H., \& Ghaderi, H. (2018). Sustainable third-party reverse logistics provider evaluation and selection using fuzzy SWARA and developed fuzzy COPRAS in the presence of risk criteria. Applied Soft Computing, 65, 307-319. https://doi.org/10.1016/j.asoc.2018.01.023.

Zavadskas, E. K., Kaklauskas, A., \& Sarka, V. (1994). The new method of multi criteria complex proportional assessment of projects. Technological and Economic Development of Economy, 1(3), 131-139.

Zheng, Y., Xu, Z., He, Y. \& Liao, H. (2018). Severity assessment of chronic obstructive pulmonary disease based on hesitant fuzzy linguistic COPRAS method. Applied Soft Computing, 69, 60-71. https://doi.org/10.1016/j.asoc.2018.04.035.

Ziaee, M., \& Bouquard, J. L. (2010). Optimal pricing and lot sizing vendor managed inventory. International Journal of Industrial Engineering Computations, 1(1), 33-44.

Ziat, A., Sefiani, N., Reklaoui, K., \& Azzouzi, H. (2019). A generic framework for hospital supply chain. International Journal of Healthcare Management, 1-8. https://doi.org/10.1080/20479700.2019.1603415.

\section{Appendix A}

\section{Table A-1}

The relative importance weight of each criteria in linguistic term

\begin{tabular}{lcccccc}
\hline \multicolumn{1}{c}{ Criteria } & DM1 & DM2 & DM3 & DM4 & DM5 & DM6 \\
\hline Institutional trust $\left(C_{1}\right)$ & - & - & - & - & - & - \\
Information sharing and exchanging $\left(C_{2}\right)$ & EI & MI & MI & LI & LI & MI \\
Information Technology readiness $\left(\mathrm{C}_{3}\right)$ & MI & MI & MI & MI & MI & LI \\
Supply Chain Process Integration $\left(\mathrm{C}_{4}\right)$ & MI & LI & LI & MI & MI & EI \\
Supplier flexibility $\left(\mathrm{C}_{5}\right)$ & MI & LI & VI & VI & LI & MI \\
Risk/ reward sharing $\left(\mathrm{C}_{6}\right)$ & LI & MI & MI & LI & LI & MI \\
Past delivery performance $\left(\mathrm{C}_{7}\right)$ & LI & VI & VI & LI & LI & LI \\
Investment cost $\left(\mathrm{C}_{8}\right)$ & VI & LI & LI & VI & MI & LI \\
Project implementation time $\left(\mathrm{C}_{9}\right)$ & LI & LI & VI & VI & LI & LI \\
\hline
\end{tabular}


Table A-2

Information of decision makers (DMs) who participate on questionnaires

\begin{tabular}{ccccc}
\hline DMs & Experience (Year) & Education & Major & Position \\
\hline 1 & 5 & Bachelor & Industrial Engineering & Engineer \\
2 & 13 & Bachelor & Management & Project Manager \\
3 & 11 & Master & Master Business Administration & Head of project management \\
4 & 9 & PhD & Industrial Engineering & Expert of R\&D \\
5 & 20 & Bachelor & Industrial Engineering & Warehouse manager \\
6 & 12 & Master & Industrial Management & Chief Project Engineer \\
\hline
\end{tabular}

Table A-3

Ratings of decision makers with respect to suppliers and criteria

\begin{tabular}{|c|c|c|c|c|c|c|c|c|c|c|c|c|c|c|c|c|c|c|}
\hline \multirow{2}{*}{$\begin{array}{c}\text { Experts } \\
\text { Criteria }\end{array}$} & \multicolumn{3}{|c|}{ DM1 } & \multicolumn{3}{|c|}{ DM2 } & \multicolumn{3}{|c|}{ DM3 } & \multicolumn{3}{|c|}{ DM4 } & \multicolumn{3}{|c|}{ DM5 } & \multicolumn{3}{|c|}{ DM6 } \\
\hline & 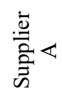 & $\begin{array}{l}\stackrel{\bar{g}}{\bar{n}} \infty \\
\overline{\bar{n}}\end{array}$ & 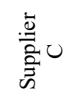 & $\begin{array}{l}\stackrel{\bar{g}}{\bar{n}} \\
\stackrel{\bar{m}}{\bar{n}}\end{array}$ & 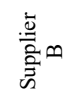 & 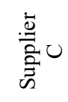 & $\begin{array}{l}\overline{\bar{g}} \\
\overline{\bar{n}} \\
\bar{n}\end{array}$ & $\begin{array}{l}\stackrel{\bar{g}}{\bar{n}} \infty \\
\stackrel{\bar{n}}{\bar{n}} \infty\end{array}$ & 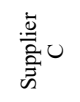 & 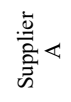 & 离 & $\begin{array}{l}\stackrel{. \bar{g}}{.} \\
\overline{\bar{n}} \\
\bar{n}\end{array}$ & 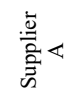 & 离 & U & $\begin{array}{l}\stackrel{\vec{g}}{\overline{2}} \\
\stackrel{\bar{\Xi}}{\bar{n}}\end{array}$ & 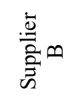 & ט. \\
\hline Institutional trust $\left(\mathrm{C}_{1}\right)$ & M & $\mathrm{L}$ & $\mathrm{H}$ & $\mathrm{H}$ & M & $\mathrm{VH}$ & M & M & $\mathrm{H}$ & M & $\mathrm{H}$ & $\mathrm{H}$ & $\mathrm{H}$ & M & $\mathrm{H}$ & M & $\mathrm{L}$ & $\mathrm{H}$ \\
\hline $\begin{array}{l}\text { Information sharing and } \\
\text { exchanging }\left(C_{2}\right)\end{array}$ & M & $\mathrm{H}$ & $\mathrm{H}$ & M & $\mathrm{H}$ & $\mathrm{H}$ & M & $\mathrm{VH}$ & M & M & M & M & M & $\mathrm{H}$ & $\mathrm{H}$ & M & $\mathrm{H}$ & M \\
\hline $\begin{array}{l}\text { Information Technology } \\
\text { readiness }\left(\mathrm{C}_{3}\right)\end{array}$ & $\mathrm{M}$ & $\mathrm{H}$ & M & M & M & M & $\mathrm{L}$ & $\mathrm{H}$ & $\mathrm{H}$ & M & $\mathrm{L}$ & $\mathrm{H}$ & M & M & M & M & $\mathrm{H}$ & $\mathrm{H}$ \\
\hline $\begin{array}{l}\text { Supply Chain Process } \\
\text { Integration }\left(\mathrm{C}_{4}\right)\end{array}$ & $\mathrm{L}$ & M & $\mathrm{H}$ & M & M & $\mathrm{VH}$ & M & $\mathrm{H}$ & M & M & $\mathrm{H}$ & $\mathrm{H}$ & M & M & $\mathrm{H}$ & M & M & M \\
\hline Supplier flexibility $\left(\mathrm{C}_{5}\right)$ & $\mathrm{H}$ & $\mathrm{H}$ & $\mathrm{VH}$ & $\mathrm{H}$ & $\mathrm{VH}$ & $\mathrm{H}$ & $\mathrm{H}$ & $\mathrm{H}$ & $\mathrm{M}$ & $\mathrm{H}$ & VH & M & $\mathrm{H}$ & VH & VH & $\mathrm{H}$ & $\mathrm{H}$ & $\mathrm{M}$ \\
\hline Risk/ reward sharing $\left(\mathrm{C}_{6}\right)$ & $\mathrm{L}$ & M & $\mathrm{L}$ & $\mathrm{VL}$ & M & $\mathrm{VL}$ & M & M & $\mathrm{VL}$ & $\mathrm{VL}$ & M & M & $\mathrm{VL}$ & M & $\mathrm{L}$ & $\mathrm{VL}$ & $\mathrm{M}$ & $\mathrm{VL}$ \\
\hline $\begin{array}{l}\text { Past delivery performance } \\
\qquad\left(\mathrm{C}_{7}\right)\end{array}$ & $\mathrm{H}$ & $\mathrm{M}$ & $\mathrm{H}$ & $\mathrm{M}$ & $\mathrm{M}$ & $\mathrm{M}$ & $\mathrm{H}$ & $\mathrm{M}$ & $\mathrm{M}$ & $\mathrm{M}$ & $\mathrm{M}$ & M & $\mathrm{M}$ & $\mathrm{M}$ & $\mathrm{H}$ & $\mathrm{M}$ & $\mathrm{M}$ & M \\
\hline Investment $\operatorname{cost}\left(\mathrm{C}_{8}\right)$ & $\mathrm{H}$ & $\mathrm{H}$ & L & $\mathrm{VH}$ & M & $\mathrm{M}$ & M & $\mathrm{H}$ & $\mathrm{M}$ & $\mathrm{H}$ & L & M & $\mathrm{VH}$ & $\mathrm{M}$ & L & $\mathrm{H}$ & $\mathrm{M}$ & $\mathrm{M}$ \\
\hline $\begin{array}{l}\text { Project implementation time } \\
\qquad\left(\mathrm{C}_{9}\right)\end{array}$ & $\mathrm{H}$ & $\mathrm{M}$ & $\mathrm{M}$ & $\mathrm{VH}$ & $\mathrm{L}$ & L & $\mathrm{H}$ & $\mathrm{M}$ & $\mathrm{L}$ & M & $\mathrm{M}$ & M & $\mathrm{H}$ & $\mathrm{L}$ & $\mathrm{M}$ & M & $\mathrm{M}$ & $\mathrm{L}$ \\
\hline
\end{tabular}

Table A-4

Sensitivity analysis of 36 scenarios

\begin{tabular}{|c|c|c|c|c|c|c|}
\hline \multirow{2}{*}{ Scenario } & \multirow{2}{*}{ Definition } & \multirow{2}{*}{$\mathrm{Q}_{\mathrm{i}}^{\text {non }}$ and $\mathrm{N}_{\mathrm{i}}$} & \multicolumn{3}{|c|}{ Supplier } & \multirow{2}{*}{ Ranking of supplier } \\
\hline & & & $\mathrm{A}$ & $\mathrm{B}$ & $\mathrm{C}$ & \\
\hline \multirow{2}{*}{$\mathrm{S}_{1}$} & \multirow{2}{*}{$\mathrm{C}_{1}-\mathrm{C}_{2}$} & $\mathrm{Q}_{\mathrm{i}}^{\text {non }}$ & 0.347 & 0.374 & 0.467 & \multirow{2}{*}{$\mathrm{C}>\mathrm{B}>\mathrm{A}$} \\
\hline & & $\mathrm{N}_{\mathrm{i}}$ & $74.30 \%$ & $80.03 \%$ & $100 \%$ & \\
\hline \multirow{2}{*}{$\mathrm{S}_{2}$} & \multirow{2}{*}{$\mathrm{C}_{1}-\mathrm{C}_{3}$} & $Q_{i}^{\text {non }}$ & 0.370 & 0.438 & 0.528 & \multirow{2}{*}{$\mathrm{C}>\mathrm{B}>\mathrm{A}$} \\
\hline & & $\mathrm{N}_{\mathrm{i}}$ & $70.16 \%$ & $81.01 \%$ & $100 \%$ & \\
\hline \multirow{2}{*}{$\mathrm{S}_{3}$} & \multirow{2}{*}{$\mathrm{C}_{1}-\mathrm{C}_{4}$} & $\mathrm{Q}_{\mathrm{i}}^{\text {non }}$ & 0.369 & 0.433 & 0.525 & \multirow{2}{*}{$\mathrm{C}>\mathrm{B}>\mathrm{A}$} \\
\hline & & $\mathrm{N}_{\mathrm{i}}$ & $70.28 \%$ & $82.43 \%$ & $100 \%$ & \\
\hline \multirow{2}{*}{$\mathrm{S}_{4}$} & \multirow{2}{*}{$\mathrm{C}_{1}-\mathrm{C}_{5}$} & $\mathrm{Q}_{\mathrm{i}}^{\text {non }}$ & 0.336 & 0.261 & 0.376 & \multirow{2}{*}{$\mathrm{C}>\mathrm{A}>\mathrm{B}$} \\
\hline & & $\mathrm{N}_{\mathrm{i}}$ & $89.55 \%$ & $69.49 \%$ & $100 \%$ & \\
\hline \multirow{2}{*}{$\mathrm{S}_{5}$} & \multirow{2}{*}{$\mathrm{C}_{1}-\mathrm{C}_{6}$} & $\mathrm{Q}_{\mathrm{i}}^{\text {non }}$ & 0.392 & 0.372 & 0.400 & \multirow{2}{*}{$\mathrm{C}>\mathrm{A}>\mathrm{B}$} \\
\hline & & $\mathrm{N}_{\mathrm{i}}$ & $97.95 \%$ & $92.89 \%$ & $100 \%$ & \\
\hline \multirow{2}{*}{$\mathrm{S}_{6}$} & \multirow{2}{*}{$\mathrm{C}_{1}-\mathrm{C}_{7}$} & $\mathrm{Q}_{\mathrm{i}}^{\text {non }}$ & 0.403 & 0.352 & 0.426 & \multirow[b]{2}{*}{$\mathrm{C}>\mathrm{A}>\mathrm{B}$} \\
\hline & & $\mathrm{N}_{\mathrm{i}}$ & $94.64 \%$ & $82.59 \%$ & $100 \%$ & \\
\hline \multirow{2}{*}{$\mathrm{S}_{7}$} & \multirow{2}{*}{$\mathrm{C}_{1}-\mathrm{C}_{8}$} & $\mathrm{Q}_{\mathrm{i}}^{\text {non }}$ & 0.251 & 0.242 & 0.273 & \multirow[b]{2}{*}{$\mathrm{C}>\mathrm{A}>\mathrm{B}$} \\
\hline & & $\mathrm{N}_{\mathrm{i}}$ & $91.89 \%$ & $88.73 \%$ & $100 \%$ & \\
\hline \multirow{2}{*}{$\mathrm{S}_{8}$} & \multirow{2}{*}{$\mathrm{C}_{1}-\mathrm{C}_{9}$} & $\mathrm{Q}_{\mathrm{i}}^{\text {non }}$ & 0.250 & 0.241 & 0.270 & \multirow{2}{*}{$\mathrm{C}>\mathrm{A}>\mathrm{B}$} \\
\hline & & $\mathrm{N}_{\mathrm{i}}$ & $92.31 \%$ & $89.29 \%$ & $100 \%$ & \\
\hline \multirow{2}{*}{$\mathrm{S}_{9}$} & \multirow{2}{*}{$\mathrm{C}_{2}-\mathrm{C}_{3}$} & $Q_{i}^{\text {non }}$ & 0.388 & 0.327 & 0.459 & \multirow{2}{*}{$\mathrm{C}>\mathrm{A}>\mathrm{B}$} \\
\hline & & $\mathrm{N}_{\mathrm{i}}$ & $84.57 \%$ & $71.22 \%$ & $100 \%$ & \\
\hline
\end{tabular}


D. Sumrit / Decision Science Letters 9 (2020)

\begin{tabular}{|c|c|c|c|c|c|c|}
\hline $\mathrm{S}_{10}$ & $\mathrm{C}_{2}-\mathrm{C}_{4}$ & $\begin{array}{c}\mathrm{Q}_{\mathrm{i}}^{\text {non }} \\
\mathrm{N}_{\mathrm{i}}\end{array}$ & $\begin{array}{c}0.388 \\
84.51 \%\end{array}$ & $\begin{array}{c}0.324 \\
70.55 \%\end{array}$ & $\begin{array}{l}0.460 \\
100 \%\end{array}$ & $\mathrm{C}>\mathrm{A}>\mathrm{B}$ \\
\hline $\mathrm{S}_{11}$ & $\mathrm{C}_{2}-\mathrm{C}_{5}$ & $\begin{array}{c}\mathrm{Q}_{\mathrm{i}}^{\text {non }} \\
\mathrm{N}_{\mathrm{i}}\end{array}$ & $\begin{array}{c}0.404 \\
93.38 \%\end{array}$ & $\begin{array}{c}0.298 \\
68.93 \%\end{array}$ & $\begin{array}{l}0.433 \\
100 \%\end{array}$ & $\mathrm{C}>\mathrm{A}>\mathrm{B}$ \\
\hline $\mathrm{S}_{12}$ & $\mathrm{C}_{2}-\mathrm{C}_{6}$ & $\begin{array}{c}\mathrm{Q}_{\mathrm{i}}^{\text {non }} \\
\mathrm{N}_{\mathrm{i}}\end{array}$ & $\begin{array}{c}0.374 \\
88.38 \%\end{array}$ & $\begin{array}{c}0.300 \\
81.16 \%\end{array}$ & $\begin{array}{l}0.399 \\
100 \%\end{array}$ & $\mathrm{C}>\mathrm{A}>\mathrm{B}$ \\
\hline $\mathrm{S}_{13}$ & $\mathrm{C}_{2}-\mathrm{C}_{7}$ & $\begin{array}{c}\mathrm{Q}_{\mathrm{i}}^{\text {non }} \\
\mathrm{N}_{\mathrm{i}}\end{array}$ & $\begin{array}{c}0.406 \\
89.90 \%\end{array}$ & $\begin{array}{c}0.315 \\
69.66 \%\end{array}$ & $\begin{array}{l}0.452 \\
100 \%\end{array}$ & $\mathrm{C}>\mathrm{A}>\mathrm{B}$ \\
\hline $\mathrm{S}_{14}$ & $\mathrm{C}_{2}-\mathrm{C}_{8}$ & $\begin{array}{c}\mathrm{Q}_{\mathrm{i}}^{\text {non }} \\
\mathrm{N}_{\mathrm{i}}\end{array}$ & $\begin{array}{c}0.336 \\
88.20 \%\end{array}$ & $\begin{array}{c}0.263 \\
69.24 \%\end{array}$ & $\begin{array}{l}0.381 \\
100 \%\end{array}$ & $\mathrm{C}>\mathrm{A}>\mathrm{B}$ \\
\hline $\mathrm{S}_{15}$ & $\mathrm{C}_{2}-\mathrm{C}_{9}$ & $\begin{array}{c}\mathrm{Q}_{\mathrm{i}}^{\text {non }} \\
\mathrm{N}_{\mathrm{i}}\end{array}$ & $\begin{array}{c}0.389 \\
88.23 \%\end{array}$ & $\begin{array}{c}0.333 \\
69.14 \%\end{array}$ & $\begin{array}{l}0.454 \\
100 \%\end{array}$ & $\mathrm{C}>\mathrm{A}>\mathrm{B}$ \\
\hline $\mathrm{S}_{16}$ & $\mathrm{C}_{3}-\mathrm{C}_{4}$ & $\begin{array}{c}\mathrm{Q}_{\mathrm{i}}^{\text {non }} \\
\mathrm{N}_{\mathrm{i}}\end{array}$ & $\begin{array}{c}0.389 \\
85.86 \%\end{array}$ & $\begin{array}{c}0.334 \\
73.59 \%\end{array}$ & $\begin{array}{l}0.453 \\
100 \%\end{array}$ & $\mathrm{C}>\mathrm{A}>\mathrm{B}$ \\
\hline $\mathrm{S}_{17}$ & $\mathrm{C}_{3}-\mathrm{C}_{5}$ & $\begin{array}{c}\mathrm{Q}_{\mathrm{i}}^{\text {non }} \\
\mathrm{N}_{\mathrm{i}}\end{array}$ & $\begin{array}{c}0.395 \\
88.28 \%\end{array}$ & $\begin{array}{c}0.338 \\
75.55 \%\end{array}$ & $\begin{array}{l}0.447 \\
100 \%\end{array}$ & $\mathrm{C}>\mathrm{A}>\mathrm{B}$ \\
\hline $\mathrm{S}_{18}$ & $\mathrm{C}_{3}-\mathrm{C}_{6}$ & $\begin{array}{c}\mathrm{Q}_{\mathrm{i}}^{\text {non }} \\
\mathrm{N}_{\mathrm{i}}\end{array}$ & $\begin{array}{c}0.383 \\
87.73 \%\end{array}$ & $\begin{array}{c}0.343 \\
78.63 \%\end{array}$ & $\begin{array}{l}0.437 \\
100 \%\end{array}$ & $\mathrm{C}>\mathrm{A}>\mathrm{B}$ \\
\hline $\mathrm{S}_{19}$ & $\mathrm{C}_{3}-\mathrm{C}_{7}$ & $\begin{array}{c}\mathrm{Q}_{\mathrm{i}}^{\text {non }} \\
\mathrm{N}_{\mathrm{i}}\end{array}$ & $\begin{array}{c}0.397 \\
88.58 \%\end{array}$ & $\begin{array}{c}0.330 \\
73.63 \%\end{array}$ & $\begin{array}{l}0.449 \\
100 \%\end{array}$ & $\mathrm{C}>\mathrm{A}>\mathrm{B}$ \\
\hline $\mathrm{S}_{20}$ & $\mathrm{C}_{3}-\mathrm{C}_{8}$ & $\begin{array}{c}\mathrm{Q}_{\mathrm{i}}^{\text {non }} \\
\mathrm{N}_{\mathrm{i}}\end{array}$ & $\begin{array}{c}0.364 \\
87.86 \%\end{array}$ & $\begin{array}{c}0.305 \\
73.48 \%\end{array}$ & $\begin{array}{l}0.415 \\
100 \%\end{array}$ & $\mathrm{C}>\mathrm{A}>\mathrm{B}$ \\
\hline $\mathrm{S}_{21}$ & $\mathrm{C}_{3}-\mathrm{C}_{9}$ & $\begin{array}{c}\mathrm{Q}_{\mathrm{i}}^{\text {non }} \\
\mathrm{N}_{\mathrm{i}}\end{array}$ & $\begin{array}{c}0.363 \\
87.04 \%\end{array}$ & $\begin{array}{c}0.304 \\
73.49 \%\end{array}$ & $\begin{array}{l}0.413 \\
100 \%\end{array}$ & $\mathrm{C}>\mathrm{A}>\mathrm{B}$ \\
\hline $\mathrm{S}_{22}$ & $\mathrm{C}_{4}-\mathrm{C}_{5}$ & $\begin{array}{c}\mathrm{Q}_{\mathrm{i}}^{\text {non }} \\
\mathrm{N}_{\mathrm{i}}\end{array}$ & $\begin{array}{c}0.391 \\
86.66 \%\end{array}$ & $\begin{array}{c}0.335 \\
74.12 \%\end{array}$ & $\begin{array}{l}0.452 \\
100 \%\end{array}$ & $\mathrm{C}>\mathrm{A}>\mathrm{B}$ \\
\hline $\mathrm{S}_{23}$ & $\mathrm{C}_{4}-\mathrm{C}_{6}$ & $\begin{array}{c}\mathrm{Q}_{\mathrm{i}}^{\text {non }} \\
\mathrm{N}_{\mathrm{i}}\end{array}$ & $\begin{array}{c}0.383 \\
86.64 \%\end{array}$ & $\begin{array}{c}0.338 \\
75.90 \%\end{array}$ & $\begin{array}{l}0.445 \\
100 \%\end{array}$ & $\mathrm{C}>\mathrm{A}>\mathrm{B}$ \\
\hline $\mathrm{S}_{24}$ & $\mathrm{C}_{4}-\mathrm{C}_{7}$ & $\begin{array}{c}\mathrm{Q}_{\mathrm{i}}^{\text {non }} \\
\mathrm{N}_{\mathrm{i}}\end{array}$ & $\begin{array}{c}0.394 \\
87.19 \%\end{array}$ & $\begin{array}{c}0.332 \\
73.54 \%\end{array}$ & $\begin{array}{l}0.451 \\
100 \%\end{array}$ & $\mathrm{C}>\mathrm{A}>\mathrm{B}$ \\
\hline $\mathrm{S}_{25}$ & $\mathrm{C}_{4}-\mathrm{C}_{8}$ & $\begin{array}{c}\mathrm{Q}_{\mathrm{i}}^{\text {non }} \\
\mathrm{N}_{\mathrm{i}}\end{array}$ & $\begin{array}{c}0.374 \\
86.78 \%\end{array}$ & $\begin{array}{c}0.318 \\
73.84 \%\end{array}$ & $\begin{array}{l}0.431 \\
100 \%\end{array}$ & $\mathrm{C}>\mathrm{A}>\mathrm{B}$ \\
\hline $\mathrm{S}_{26}$ & $\mathrm{C}_{4}-\mathrm{C}_{9}$ & $\begin{array}{c}\mathrm{Q}_{\mathrm{i}}^{\text {non }} \\
\mathrm{N}_{\mathrm{i}}\end{array}$ & $\begin{array}{c}0.373 \\
86.84 \%\end{array}$ & $\begin{array}{c}0.317 \\
73.85 \%\end{array}$ & $\begin{array}{l}0.429 \\
100 \%\end{array}$ & $\mathrm{C}>\mathrm{A}>\mathrm{B}$ \\
\hline $\mathrm{S}_{27}$ & $\mathrm{C}_{5}-\mathrm{C}_{6}$ & $\begin{array}{c}\mathrm{Q}_{\mathrm{i}}^{\text {non }} \\
\mathrm{N}_{\mathrm{i}}\end{array}$ & $\begin{array}{c}0.387 \\
85.48 \%\end{array}$ & $\begin{array}{c}0.335 \\
74.13 \%\end{array}$ & $\begin{array}{l}0.452 \\
100 \%\end{array}$ & $\mathrm{C}>\mathrm{A}>\mathrm{B}$ \\
\hline $\mathrm{S}_{28}$ & $\mathrm{C}_{5}-\mathrm{C}_{7}$ & $\begin{array}{c}\mathrm{Q}_{\mathrm{i}}^{\text {non }} \\
\mathrm{N}_{\mathrm{i}}\end{array}$ & $\begin{array}{c}0.389 \\
85.57 \%\end{array}$ & $\begin{array}{c}0.332 \\
73.03 \%\end{array}$ & $\begin{array}{l}0.455 \\
100 \%\end{array}$ & $\mathrm{C}>\mathrm{A}>\mathrm{B}$ \\
\hline $\mathrm{S}_{29}$ & $\mathrm{C}_{5}-\mathrm{C}_{8}$ & $\begin{array}{c}\mathrm{Q}_{\mathrm{i}}^{\text {non }} \\
\mathrm{N}_{\mathrm{i}}\end{array}$ & $\begin{array}{c}0.372 \\
84.84 \%\end{array}$ & $\begin{array}{c}0.319 \\
72.65 \%\end{array}$ & $\begin{array}{l}0.439 \\
100 \%\end{array}$ & $\mathrm{C}>\mathrm{A}>\mathrm{B}$ \\
\hline $\mathrm{S}_{30}$ & $\mathrm{C}_{5}-\mathrm{C}_{9}$ & $\begin{array}{c}\mathrm{Q}_{\mathrm{i}}^{\text {non }} \\
\mathrm{N}_{\mathrm{i}}\end{array}$ & $\begin{array}{c}0.376 \\
85.05 \%\end{array}$ & $\begin{array}{c}0.323 \\
73.01 \%\end{array}$ & $\begin{array}{l}0.442 \\
100 \%\end{array}$ & $\mathrm{C}>\mathrm{A}>\mathrm{B}$ \\
\hline $\mathrm{S}_{31}$ & $\mathrm{C}_{6}-\mathrm{C}_{7}$ & $\begin{array}{c}\mathrm{Q}_{\mathrm{i}}^{\text {non }} \\
\mathrm{N}_{\mathrm{i}}\end{array}$ & $\begin{array}{c}0.390 \\
85.83 \%\end{array}$ & $\begin{array}{c}0.332 \\
73.04 \%\end{array}$ & $\begin{array}{l}0.455 \\
100 \%\end{array}$ & $\mathrm{C}>\mathrm{A}>\mathrm{B}$ \\
\hline $\mathrm{S}_{32}$ & $\mathrm{C}_{6}-\mathrm{C}_{8}$ & $\begin{array}{c}\mathrm{Q}_{\mathrm{i}}^{\text {non }} \\
\mathrm{N}_{\mathrm{i}}\end{array}$ & $\begin{array}{c}0.386 \\
85.72 \%\end{array}$ & $\begin{array}{c}0.327 \\
72.74 \%\end{array}$ & $\begin{array}{l}0.450 \\
100 \%\end{array}$ & $\mathrm{C}>\mathrm{A}>\mathrm{B}$ \\
\hline $\mathrm{S}_{33}$ & $\mathrm{C}_{6}-\mathrm{C}_{9}$ & $\begin{array}{c}\mathrm{Q}_{\mathrm{i}}^{\text {non }} \\
\mathrm{N}_{\mathrm{i}}\end{array}$ & $\begin{array}{c}0.385 \\
85.71 \%\end{array}$ & $\begin{array}{c}0.325 \\
72.50 \%\end{array}$ & $\begin{array}{l}0.449 \\
100 \%\end{array}$ & $\mathrm{C}>\mathrm{A}>\mathrm{B}$ \\
\hline $\mathrm{S}_{34}$ & $\mathrm{C}_{7}-\mathrm{C}_{8}$ & $\begin{array}{c}\mathrm{Q}_{\mathrm{i}}^{\text {non }} \\
\mathrm{N}_{\mathrm{i}}\end{array}$ & $\begin{array}{c}0.384 \\
85.68 \%\end{array}$ & $\begin{array}{c}0.332 \\
73.53 \%\end{array}$ & $\begin{array}{l}0.451 \\
100 \%\end{array}$ & $\mathrm{C}>\mathrm{A}>\mathrm{B}$ \\
\hline $\mathrm{S}_{35}$ & $\mathrm{C}_{7}-\mathrm{C}_{9}$ & $\begin{array}{c}\mathrm{Q}_{\mathrm{i}}^{\text {non }} \\
\mathrm{N}_{\mathrm{i}}\end{array}$ & $\begin{array}{c}0.385 \\
85.63 \%\end{array}$ & $\begin{array}{c}0.331 \\
73.53 \%\end{array}$ & $\begin{array}{l}0.450 \\
100 \%\end{array}$ & $\mathrm{C}>\mathrm{A}>\mathrm{B}$ \\
\hline $\mathrm{S}_{36}$ & $\mathrm{C}_{8}-\mathrm{C}_{9}$ & $\begin{array}{c}\mathrm{Q}_{\mathrm{i}}^{\text {non }} \\
\mathrm{N}_{\mathrm{i}}\end{array}$ & $\begin{array}{c}0.389 \\
85.76 \%\end{array}$ & $\begin{array}{c}0.333 \\
73.49 \%\end{array}$ & $\begin{array}{l}0.454 \\
100 \%\end{array}$ & $\mathrm{C}>\mathrm{A}>\mathrm{B}$ \\
\hline
\end{tabular}


(C) 2020 by the authors; licensee Growing Science, Canada. This is an open access article distributed under the terms and conditions of the Creative Commons Attribution (CC-BY) license (http://creativecommons.org/licenses/by/4.0/). 